\title{
Possibility of a Solution of the Sustainability of Transport and Mobility with the Application of Discrete Computer Simulation-A Case Study
}

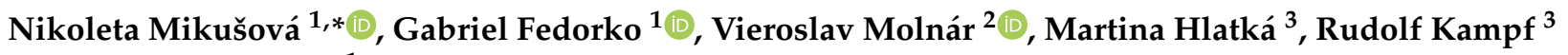 \\ and Veronika Sirková 1 \\ 1 Faculty of Mining, Ecology, Process Control and Geotechnologies, Technical University of Košice, Letná 9, \\ 04200 Košice, Slovakia; gabriel.fedorko@tuke.sk (G.F.); sirkova1982@azet.sk (V.S.) \\ 2 Faculty of Manufacturing Technologies, Technical University of Košice, Bayerova 1, 08001 Prešov, Slovakia; \\ vieroslav.molnar@tuke.sk \\ 3 Faculty of Technology, The Institute of Technology and Business in České Budějovice, \\ 37001 České Budějovice, Czech Republic; hlatka@mail.vstecb.cz (M.H.); kampf@mail.vstecb.cz (R.K.) \\ * Correspondence: nikoleta.mikusova@tuke.sk
}

check for updates

Citation: Mikušová, N.; Fedorko, G.; Molnár, V.; Hlatká, M.; Kampf, R.; Sirková, V. Possibility of a Solution of the Sustainability of Transport and Mobility with the Application of Discrete Computer Simulation-A Case Study. Sustainability 2021, 13, 9816. https://doi.org/10.3390/ su13179816

Academic Editor: Elżbieta Macioszek

Received: 3 August 2021

Accepted: 28 August 2021

Published: 1 September 2021

Publisher's Note: MDPI stays neutral with regard to jurisdictional claims in published maps and institutional affiliations.

Copyright: (c) 2021 by the authors. Licensee MDPI, Basel, Switzerland. This article is an open access article distributed under the terms and conditions of the Creative Commons Attribution (CC BY) license (https:/ / creativecommons.org/licenses/by/ $4.0 /)$.

\begin{abstract}
The paper is focused on an example of a solution for the sustainability of transport and mobility with the application of discrete computer simulation. The obtained results from the realized simulation were complemented with the selected multi-criteria decision-making method, namely the analytic hierarchy process (AHP) method. The paper describes the use of the simulation model for obtaining characteristics of alternative solutions that were designed for the needs of transport sustainability. The aim is to address the problem of traffic congestion in urban agglomerations. The simulation model serves as a means to provide information for the needs of their analysis by multi-criteria evaluation by the AHP. The methodology is based on a combination of computer simulation and multi-criteria decision-making and presents a useful tool that can be used in the field of transport sustainability. The paper notes methods to implement analysis of alternative solutions in transport. However, this procedure can also be used to solve other problems in the field of logistics systems. The paper compares five possible solutions for the organization of transport at intersections. Multi-criteria decision-making was realized based on 12 criteria. The result was the solution that reduced the length of congestion in almost all directions, with a maximum shortening of $69 \mathrm{~m}$ and a shortening of the average delay by $26 \mathrm{~s}$ compared to the current state.
\end{abstract}

Keywords: transport; sustainability; mobility; simulation

\section{Introduction}

Sustainable transport within urban agglomerations creates conditions that ensure reliable satisfaction of transport needs and the functioning of individual transport systems. The aim is to ensure the smooth travel of the population, promote public passenger transport, improve the environment, and increase safety and the flow of traffic [1]. To achieve sustainable cities, it is essential to create and sustain changes in people's social behavior through new approaches to mobility, from inefficient, uneconomical, and motorized means, to cleaner, greener, healthier, and more economical means. One of the solutions implemented in connection with sustainable mobility is the support of public passenger transport.

This relates to increasing its attractiveness, with the aim to encourage passengers to switch from individual motoring to public transport. To achieve this aim, it is necessary to create such preconditions within the transport infrastructure that public passenger transport runs continuously, without undue delay, and allows a continuous form of transport [2].

Sustainable mobility within urban agglomerations is closely linked to the effect of transport on the environment. In this regard, it is possible to talk about the importance of 
green city transport [3]. One of the key tasks is to realize measures to reduce emissions of toxic substances into the environment, the interaction of the car with the environment [4], and if it is possible to reduce the traffic volume in cities [5].

In addition, environmentally friendly vehicles are a key element of green transportation in modern economies [6]. However, it must be emphasized that the use of these types of vehicles can depend on the financial and economic situation of cities. As such, their use faces challenges in the countries of Eastern Europe.

This problem can be solved using traffic planning, whose importance is due to the growth of car traffic in cities. For this reason, cities are beginning to implement town planning measures aimed at improving the traffic situation, reducing congestion with a focus on public transport, and improving the environment [6]. One of the possible tools can be a Transportation Management Information Systems (TMIS) with the overall social and economic development, such as improvement of regional conditions and optimization of the environment, promoting communication and accelerating development [7]. It is very important for the cities to guarantee the efficiency and also the accuracy of the transportation system. One of the ways how to achieve this aim is to analyze the real-time status of transportation network, which determines the urban distribution, travel activities, and development of the urban systems [8]. In relation to the discussion above, real-time traffic prediction based on highly accurate spatio-temporal datasets of traffic sensors is a major challenge for intelligent transportation systems and sustainability. However, this is challenging due to complex topological dependencies and high dynamics associated with changes in road conditions [9]. An important topic of research in the field of modern intelligent traffic systems (ITSs) is path planning. Complex and changeable factors, for example, traffic congestion and traffic accident, should be considered by planning paths, and path point planning schemes can improve the reliability of path planning and also ensure several services needed for transportation process [10].

Town planning measures can be based on decision-making processes using a comparison of variants and partial solutions. The aim is to find a realistic transport scenario that can meet all the basic requirements associated with congestion.

One approach to traffic planning is the well-known microscopic traffic simulator, Simulation of Urban Mobility (SUMO), which is used to design traffic scenarios and present their parameters, in addition to the evaluation and validation of traffic requirements and mobility patterns [11]. The interdependencies among multimodal modes of transport significantly contribute to effective urban transport planning [11].

Due to the complexity of traffic problems, new approaches based on computer simulation and traffic modeling are increasingly being introduced.

It is possible to effectively use simulation models with different levels of detail [11]. For example, it is possible to use macroscopic traffic simulations, which focus on traffic streams but do not take into account the vehicles of the traffic stream. By contrast, microsimulation is a form of traffic simulation capable of accurately modeling the behavior of vehicles in a defined environment [11]. The importance of real data for microsimulation purposes of urban mobility monitoring can be noted by examining the mobility of vehicles at two daily peak times at a roundabout [12]. For the need of micro and macrosimulations, it is possible to use Internet of Things (IoT). IoT-based solution also presents an interesting tool for traffic problems solution. Internet of Things can be used in the daunting task of quickly identifying vulnerable network sections [13]. IoT can provide data transmission and their storage in the form of Big Data [14]. The obtained data are possible to use for real-time planning. Another interesting technology related with the data storage is a blockchain technology, which is a combination of distributed data storage, timestamp technology, and peer-to-peer network. This technology also can provide a solution for the secure distributed cloud data storage system. [15]

Several software packages are used for traffic simulation. One interesting example is the PTV Vissim software that realistically simulates complex vehicles interactions at the microscopic level [16]. This software can be applied to the simulation of future traffic and 
transit conditions [17], and the obtained results can present the potential to reduce vehicle travel times and delays [17]. This software can be used for testing several scenarios relating to the effectiveness of increased safety of toll plazas [18]. This software and the resultant simulation models allow the optimal efficiency of the road network to be determined-for example, in a viaduct-hence allowing traffic management proposals to be made to reduce delays [19]. PTV Vissim can be used to simulate the effects of congestion and delays on a motorway network due to an accident, and then to apply a quantified regression formula to predict the time of traffic recovery [20]. This software and simulation models can evaluate road improvements or new traffic management strategies in different weather conditions [21]. With the help of the standard microscopic simulation platform of PTV Vissim, it is possible to compare the efficiency characteristics of algorithms for autonomous intersection control [22].

In addition to computer simulation tools, it is suitable and effective to implement other methods to support the complex and difficult problems of the sustainability of transport, particularly in the field of research [23]. One possible approach is the use of multi-criteria decision-making (MCDM). It must be emphasized that the MCDM regarding public transportation presents a complicated task that involves environmental, economic, and socio-political issues [24]. However, several studies have applied this approach to solve different transport problems, for example, the use of MCDM for decision-making relating to alternative fuel public transport buses [25], selection of sustainable urban transportation alternatives using fuzzy multi-criteria decision-making (FMCDM) [26], use of analytical hierarchical process (AHP) for the selection of suitable vehicles [27], use of AHP to determine the best solutions by traffic planning [28], and use of AHP for design and evaluate highway routes [29].

This literature review provides interesting combinations of MCDM and the simulation approach. This combination can be also used for the solution of transport sustainability and transport problems, for example, modeling and testing of different intersections using Vissim software, followed by generation of the AHP model using the PTV Vissim results or using AHP to solve traffic issues that arise due to ad hoc urban planning by changing road geometries and signaling model alternative solutions via PTV Vissim software [30-32]. This idea is also presented in this paper.

The goal of this paper is to note the possibilities of using the information provided by experts, using the simulation software PTV Vissim, and implementation of the simulation results in the proposed AHP model. By experts, we mean specialists for realization and evaluation of traffic survey. These are specialists who carried out a traffic survey at the examined transport hub, and subsequently, their data were used for the creation of a simulation model.

A novelty of the paper is the application of AHP for the selection of a suitable alternative based on the results of simulation experiments. In comparison to a recently published paper [30], which focuses on evaluating the quality of public passenger transport using AHP, the present paper focuses on the solution associated with changing the transport organization, which will not only have an impact on the quality of public transport but will also benefit the environment. The paper also demonstrates its application in the field of transport problems. A similar issue is also presented in [31], but this research study uses multi-criteria decision-making for evaluation and diagnostics of urban streets through an integrated multi-criteria model of a sustainable nature.

\section{Materials and Methods}

Addressing the issue of transport sustainability is dependent on the relevance of the criteria used, which is one of the most critical points of the many techniques available to derive decision-making solutions [32]. The selection of criteria and the sequence of steps in the analysis of transport sustainability is a challenging process [33]. The approach to the solution of transport sustainability includes several steps, of which the first is the 
identification of the sustainability assessment criteria. Computer simulation is often used in this process.

The use of computer simulation to tackle transport problems is described by the algorithm in Figure 1. This suggests that computer simulation can be used twice. The first use is within the analytical phase when the simulation model is amassing data and materials to suggest a solution. The second use of the simulation model is implemented in the designing phase when it is necessary to conduct a large number of experiments and evaluations with the intent to assess individual alternative solutions. This simulation method can also be used to compare the original state with the suggested solution. In the future, the resulting model may be applied to the traffic of the transport process and to answer "what if?" questions.

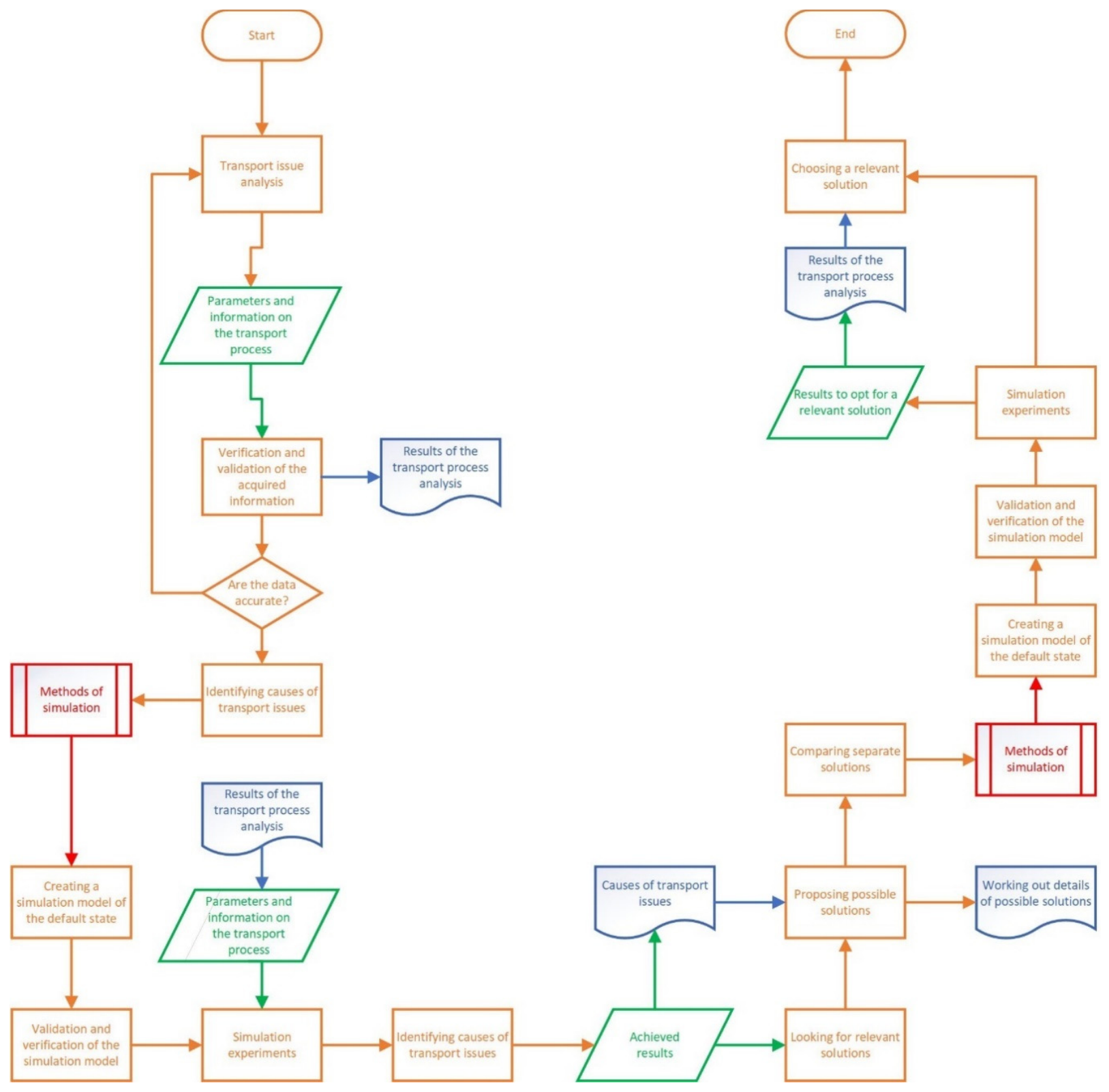

Figure 1. The algorithm solving the transport problem using computer simulation on a micro-level.

The use of the simulation model in the area of transport based on a case study referring to an actual traffic hub in the city of Uherské Hradiště in the Czech Republic is presented in the next section of the article. 


\section{Described Solution of the Traffic Hub}

The traffic hub was constructed as a level intersection with light signaling to manage the traffic. This research was conducted in the territory of Uherské Hradiště, Kunovice, and Staré Město, using the transport plan of the city from 2015. The data from research carried out in different directions show a cartogram of a transport network loaded by individual car transport within $8 \mathrm{~h}$ of the research's duration in the above-mentioned territory. Figure 2 shows a section of the surroundings of the designated traffic hub.

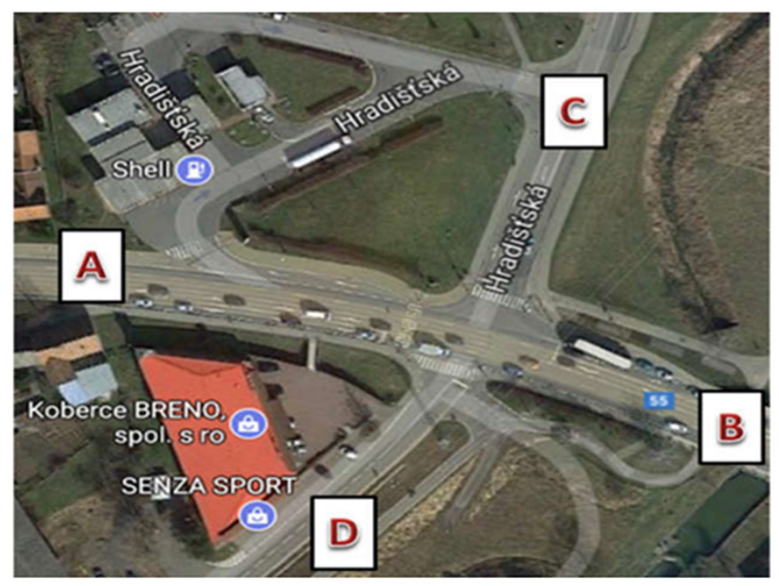

Figure 2. The surroundings of the analyzed traffic hub.

The research duration was $8 \mathrm{~h}$; from 6:00 to 10:00 a.m. and from 2:00 to 6:00 p.m. Passing vehicles were recorded within a time interval of $30 \mathrm{~min}$. The time and scope of the research were chosen in terms of when the researched transport hub was characterized by the creation of traffic congestions.

The traffic hub is situated on the traffic artery connecting Kunovice, Uherské Hradiště, and Staré Město (Figure 2). The traffic volume is greatest on the east-west axis in both directions. The traffic situation is complicated in this hub by severe traffic congestions during the rush hour.

Vehicles approach the hub from the eastern side (B) over bridges leading across the arm of the river. In this direction, the intersection consists of three lanes:

- straight direction with a possibility to turn left,

- straight direction,

- short turning lane to the right.

The other side (A) has two lanes:

- straight direction with a possibility to turn left,

- straight direction with a possibility to turn right.

The southern part of the intersection (D) has only two opposite lanes. The northern part (C) is an industrial and commercial quarter. There are a shopping center and different business networks-food, fashion shops, electronics, or hobby shops. There is also a company whose business relates to spare parts for different types of cars. In the immediate surroundings of the intersection, there is an industrial zone with a large number of passing lorries even though a new bypass was built especially so as not to overload the traffic hub.

The total number of passing vehicles in a specific direction is recorded as $\sum$ vehicles in Table 1. The number of lorries and buses from the total number of passing vehicles is expressed in L + B. Figures 3 and 4 represent passing vehicles moving in the prescribed directions. The figures were drawn according to the general city transport plan. 
Table 1. The traffic intensity of the Hradišt'ská-Východní intersection.

\begin{tabular}{|c|c|c|c|c|c|c|c|c|}
\hline \multirow{3}{*}{ Entry A } & $\sum$ Vehicles & \multirow[t]{2}{*}{$\mathrm{L}+\mathrm{B}$} & \multirow{3}{*}{$\frac{\text { EVehicles }}{358}{ }^{\text {A-C }}$} & \multirow{2}{*}{$\mathbf{L}+\mathbf{B}$} & \multirow{3}{*}{$\frac{\sum \text { Vehicles }}{32^{\text {A-D }}}$} & \multirow{2}{*}{$L+B$} & \multicolumn{2}{|c|}{ Together } \\
\hline & A-B & & & & & & Evehicles & $\mathrm{L}+\mathrm{B}$ \\
\hline & 4815 & 212 & & 5 & & 0 & 5205 & 217 \\
\hline \multirow{2}{*}{ Entry B } & \multicolumn{2}{|c|}{ B-A } & \multicolumn{2}{|c|}{$B-C$} & \multicolumn{2}{|c|}{ B-D } & & \\
\hline & 3499 & 247 & 2530 & 125 & 121 & 0 & 6150 & 372 \\
\hline \multirow{2}{*}{ Entry C } & \multicolumn{2}{|l|}{ C-A } & \multicolumn{2}{|c|}{ C-B } & \multicolumn{2}{|c|}{ C-D } & & \\
\hline & 404 & 7 & 2732 & 108 & 38 & 0 & 3174 & 115 \\
\hline \multirow{2}{*}{ Entry D } & \multicolumn{2}{|c|}{ D-A } & \multicolumn{2}{|c|}{ D-B } & \multicolumn{2}{|c|}{ D-C } & & \\
\hline & 18 & 0 & 83 & 1 & 19 & 1 & 120 & 2 \\
\hline
\end{tabular}

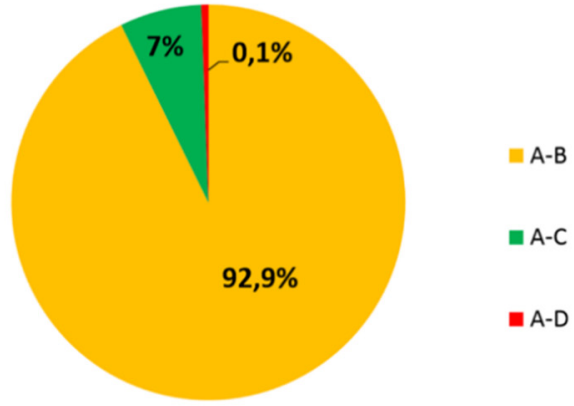

Vehicles dispersal from direction A

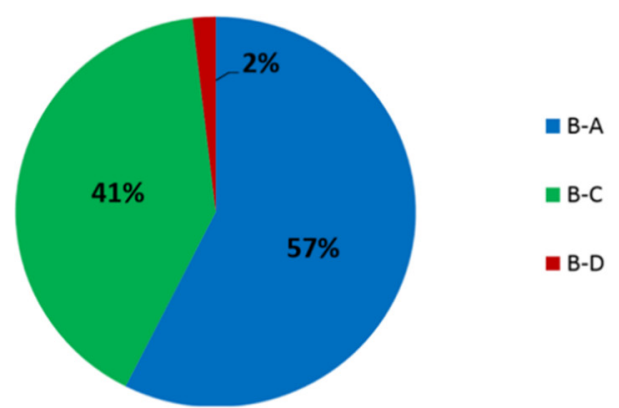

Vehicles dispersal from direction B

Figure 3. Vehicles' dispersal from direction A and direction B.

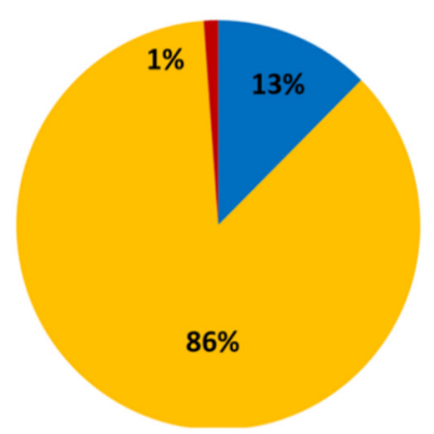

Vehicles dispersal from direction $\mathrm{C}$

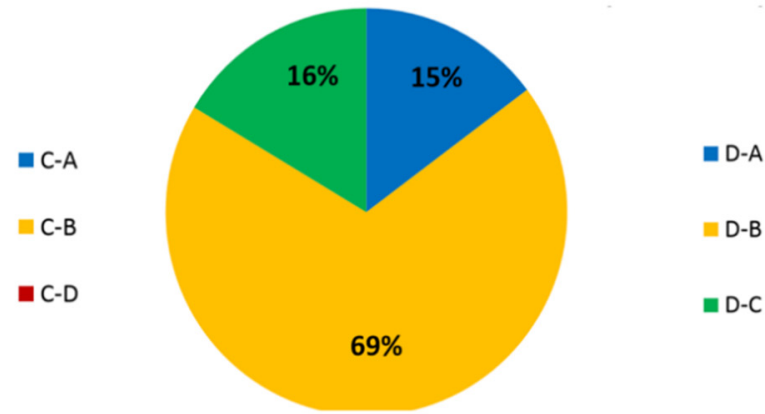

Vehicles dispersal from direction D

Figure 4. Vehicles' dispersal from direction $\mathrm{C}$ and direction D.

Each direction is colored as follows:

- A-Staré Město-blue;

- B-Uherské Hradiště-yellow;

- $\mathrm{C}$-Commercial and industrial zone-green;

- D-Quay-red.

Most vehicles coming from Staré Město continue on the main road to Uherské Hradiště. Figure 3 shows that only $7 \%$ of the vehicles turn to the shopping centers, and it does not cause significant delay at the traffic light.

The B direction (Figure 3) experiences a more significant dispersal than that of A. Most vehicles from Uherské Hradiště go on to Staré Město; however, $41 \%$ of the vehicles turn to the shopping centers. The vehicles turning at the light signal slow the traffic because there is a short turning lane, and when the light is green, the vehicles have to let pedestrians cross the road, as suggested in Figure 4.

Upon leaving the shopping centers, most vehicles continue to Uherské Hradiště (Figure 4). Traffic congestions are caused by a large number of vehicles heading to the shopping center and the short duration of the green signal (18 s). The number of vehicles 
from direction D (Figure 4) is negligible (120 vehicles) considering the total number of vehicles at the intersection. No traffic congestion negatively influences the situation at the specific traffic hub.

Figures 3 and 4 suggest that the most problematic directions are as follows (considering traffic congestion):

- Uherské Hradiště to shopping centers direction;

- $\quad$ shopping centers to Uherské Hradiště direction;

- the main route: Uherské Hradiště-Staré Město, in both directions.

The analysis results suggested four possible solutions to the existing situation at the traffic hub. These solutions were compared with a computer simulation method. The following solutions were proposed:

- change in vehicle composition, excluding lorries from the intersection;

- change in the traffic route from the Staré Město direction;

- using a roundabout;

- change in the cycle of light signalization.

\section{Results}

To create a simulation model, the PTV Vissim program was applied. The program is based on a multipurpose microscopic simulation of traffic. The program PTV Vissim allows to realize a multipurpose microscopic traffic simulation based on the behavior of participants and also allows to examine and optimize traffic flows. This program contains a wide range of applications for modeling urban and motorway traffic and the integration of public and passenger transport. Visualization of operating conditions is at a high level [34].

The road network is represented by nodes located at intersections and connectors that are on-road segments. Within the model, the road has defined the following properties:

- $\quad$ start and end coordinates,

- number of traffic lanes for sections,

- $\quad$ width of the traffic lane, and

- type of vehicles passing on the road.

Roads and connectors are the basic building blocks for adding more infrastructure objects. System elements are divided into different classes and spatial resolutions. Modeling of the transport system in this program is dependent on the specification of vehicles that will be used in the simulation model. Vehicles have the option of choosing the route. The vehicles are divided into categories in the model. Each category has a specific model of vehicle with mandatory technical characteristics, namely length, width, maximum speed, and deceleration and acceleration of the vehicle. The vehicles are generated randomly at the beginning by the function "vehicle inputs."

The program PTV Vissim analyzes and optimizes traffic flows. This program comprises a large scale of applications for modeling the city and highway traffic and integrating public and passenger transport. The visualization of traffic ratios is undertaken at a high standard. The workstation was equipped with the processor Intel Core i9-8950HK and the graphic card nVidia GeForce GTX 1080 8GB DDR5 [34].

The road network in the simulation model is represented by traffic hubs placed at intersections and by connectors at road segments. In this case, four routes are integrated with the use of connectors.

The model is defined by these characteristics:

- $\quad$ beginning and end coordinates;

- number of traffic lanes for individual segments;

- lane width;

- type of vehicles passing through a specific route.

Routes and connectors decide whether and which infrastructure objects should be added. Elements of the system are classified into various classes and 3D definitions. Placing an object is related to a specific traffic lane, which means that objects relevant to a specific 
traffic hub must be implemented in all segments. A local object does not have a physical length allocated, which means the object must be allocated in one specific point of a traffic lane. These point objects were used for the model:

- traffic signs "Give way" and "Stop";

- traffic sign "Main road";

- light signalization.

Vehicles randomly stop $0.5-1.5 \mathrm{~m}$ before the specific signal. Three-dimensional objects with defined lengths emerge at a specific position of the lane. The objects used to define the infrastructure are:

- detectors;

- $\quad$ speed areas.

When modeling the system, it is necessary to specify vehicles located in a particular infrastructure. Passenger vehicles may choose a route. The model is classified into:

- $\quad$ passenger transport and vans;

- haulage.

Individual categories include a specific vehicle model with mandatory technical characteristics, which are length, width, maximal speed, deceleration, and acceleration of the vehicle. Vehicles are randomly generated at the beginning of routes using the Vehicle Inputs function.

The numbers of vehicles included in the model and dispersal of the traffic flow through the Relative Flows function are suggested in Table 2.

Table 2. Number of vehicles and dispersal of the traffic flow in the simulation model.

\begin{tabular}{|c|c|c|c|c|c|}
\hline Source & Destination & $\begin{array}{c}\text { Dispersal of the } \\
\text { Traffic Flow }\end{array}$ & $\begin{array}{l}\text { Number of } \\
\text { Vehicles }\end{array}$ & $\begin{array}{l}\text { Number of } \\
\text { Vehicles on the } \\
\text { Specific Route }\end{array}$ & $\begin{array}{c}\text { Composition } \\
\text { of the Traffic } \\
\text { Flow }\end{array}$ \\
\hline \multirow{3}{*}{ A } & B & 0.925 & \multirow{3}{*}{5205 veh/h } & & \multirow{3}{*}{$\begin{array}{l}\text { car } \\
\text { lorry }\end{array}$} \\
\hline & $\mathrm{D}$ & 0.006 & & 4988 & \\
\hline & C & 0.069 & & 217 & \\
\hline \multirow{3}{*}{ B } & A & 0.569 & \multirow{3}{*}{$6150 \mathrm{veh} / \mathrm{h}$} & & \multirow{3}{*}{$\begin{array}{l}\text { car } \\
\text { lorry }\end{array}$} \\
\hline & C & 0.411 & & 5778 & \\
\hline & $\mathrm{D}$ & 0.020 & & 372 & \\
\hline \multirow{3}{*}{ C } & A & 0.127 & \multirow{3}{*}{3174 veh/h } & & \multirow{3}{*}{$\begin{array}{l}\text { car } \\
\text { lorry }\end{array}$} \\
\hline & D & 0.012 & & $\begin{array}{c}3059 \\
115\end{array}$ & \\
\hline & B & 0.861 & & & \\
\hline \multirow{3}{*}{$\mathrm{D}$} & $\mathrm{C}$ & 0.158 & \multirow{3}{*}{$120 \mathrm{veh} / \mathrm{h}$} & & \multirow{3}{*}{$\begin{array}{l}\text { car } \\
\text { lorry }\end{array}$} \\
\hline & A & 0.150 & & 118 & \\
\hline & B & 0.692 & & 2 & \\
\hline
\end{tabular}

"Volume" represents the number of vehicles generated on the specific route. "Vehcomp" refers to the composition of the traffic flow, in which 3 means passenger transport and 2 is haulage. For A and D directions, the total should equal 1; this result shows that all included vehicles were dispersed into the designated directions.

Vissim includes the light signalization at intersections in the infrastructure. The cycle length of the light signalization is influenced by dispositions of the traffic hub, traffic load, number of cycle phases, form of turning, length of the pedestrian crossing, and construction work at the intersection. The length I determined by fixed split times.

The cycle length at the Hradišt'ská-Východní-Zrezavice intersection is modified according to rush hours in the morning and the afternoon and on weekends and holidays. The morning cycle lasts $65 \mathrm{~s}$, the afternoon cycle $80 \mathrm{~s}$, and the cycle during holidays is $100 \mathrm{~s}$. 
Figure 5 suggests a signal program for the intersection in Uherské Hradiště. The cycle length is $65 \mathrm{~s}$ in the basic model. The duration of the color green for individual directions is as follows:

- direction from Uherské Hradiště-33 s;

- direction from Staré Město-33 s;

- direction from the industrial and commercial zone-18 s;

- direction from the quay-5 s.

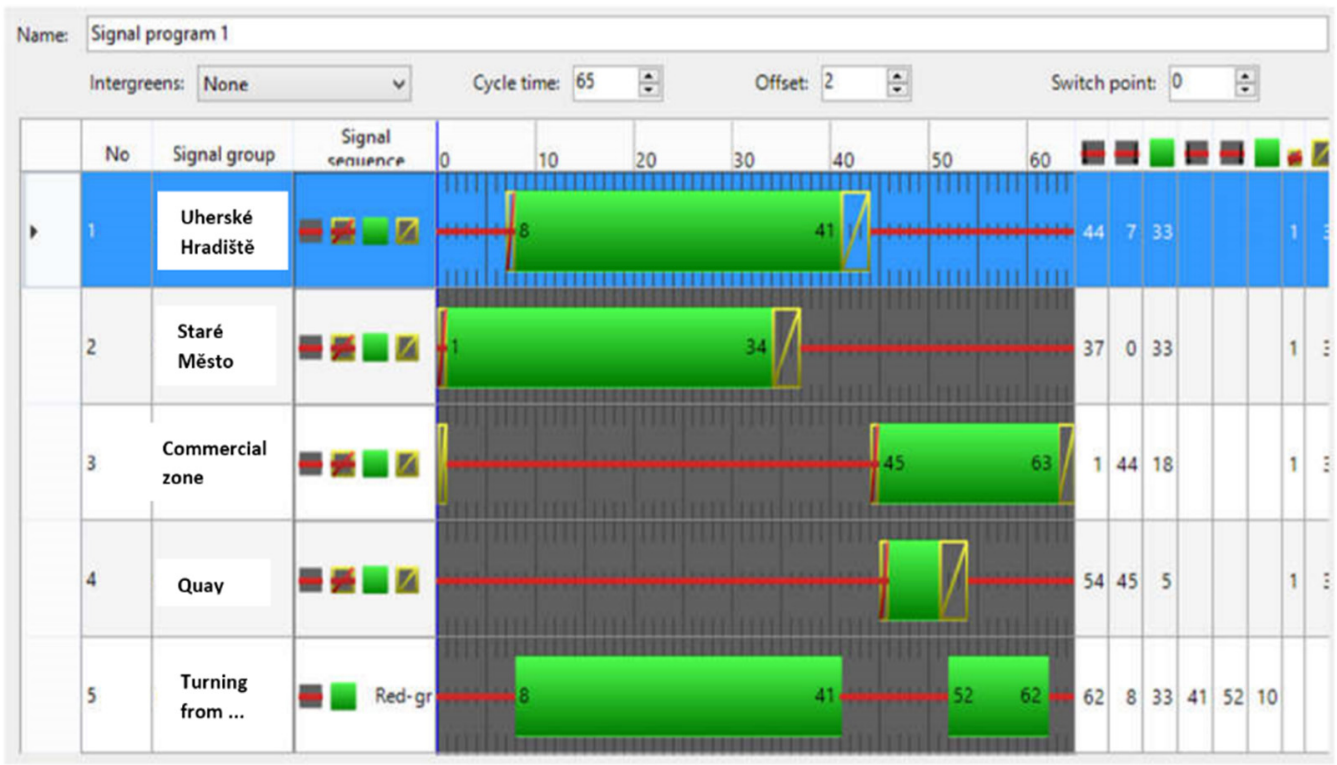

Figure 5. A signal program for a modeled traffic hub in Uherské Hradiště.

When the green light is on, it is possible to turn right from the industrial area in the direction of Uherské Hradiště. The specific layout of the intersection (Figure 6) overlaps the green wave from the Uherské Hradiště direction with the green wave from Staré Město, which results in downtime when turning from Staré Město toward the commercial and industrial zone.

Simulation experiments were realized using the simulation models, the results of which present the basic characteristics of variants (Tables 3-5).

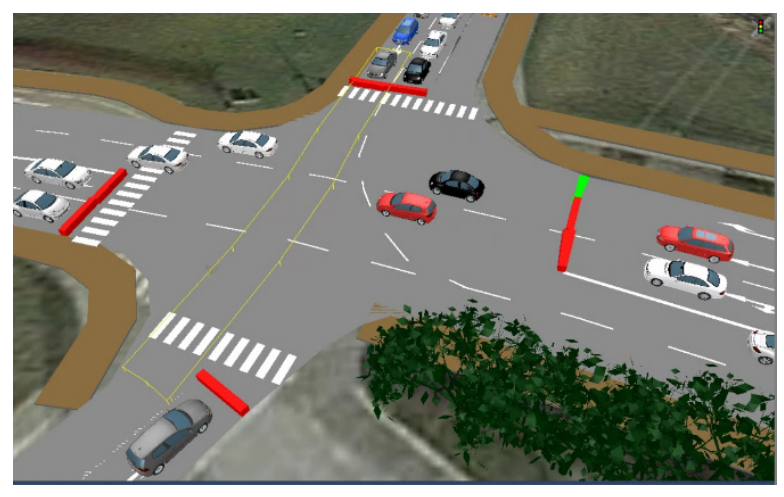

(a) turning right from the industrial zone in the direction of Uherské Hradiště (when the green line is on)

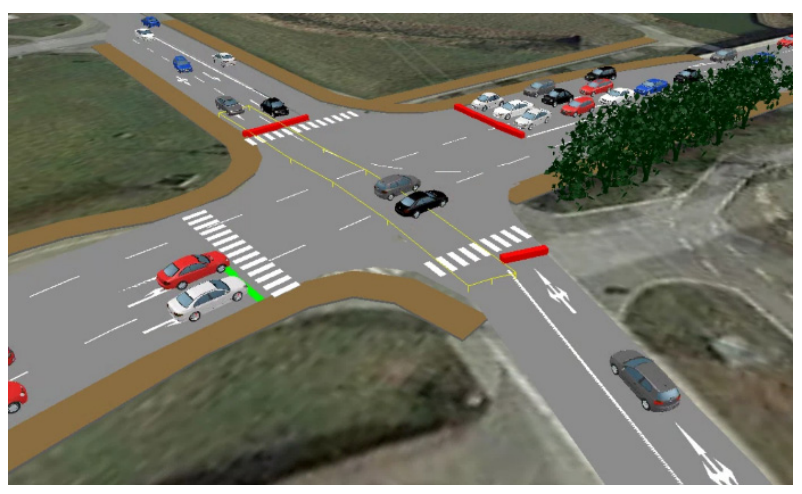

(b) downtime in turning from the direction Staré Město toward the commercial and industrial zone;

Figure 6. Cont. 


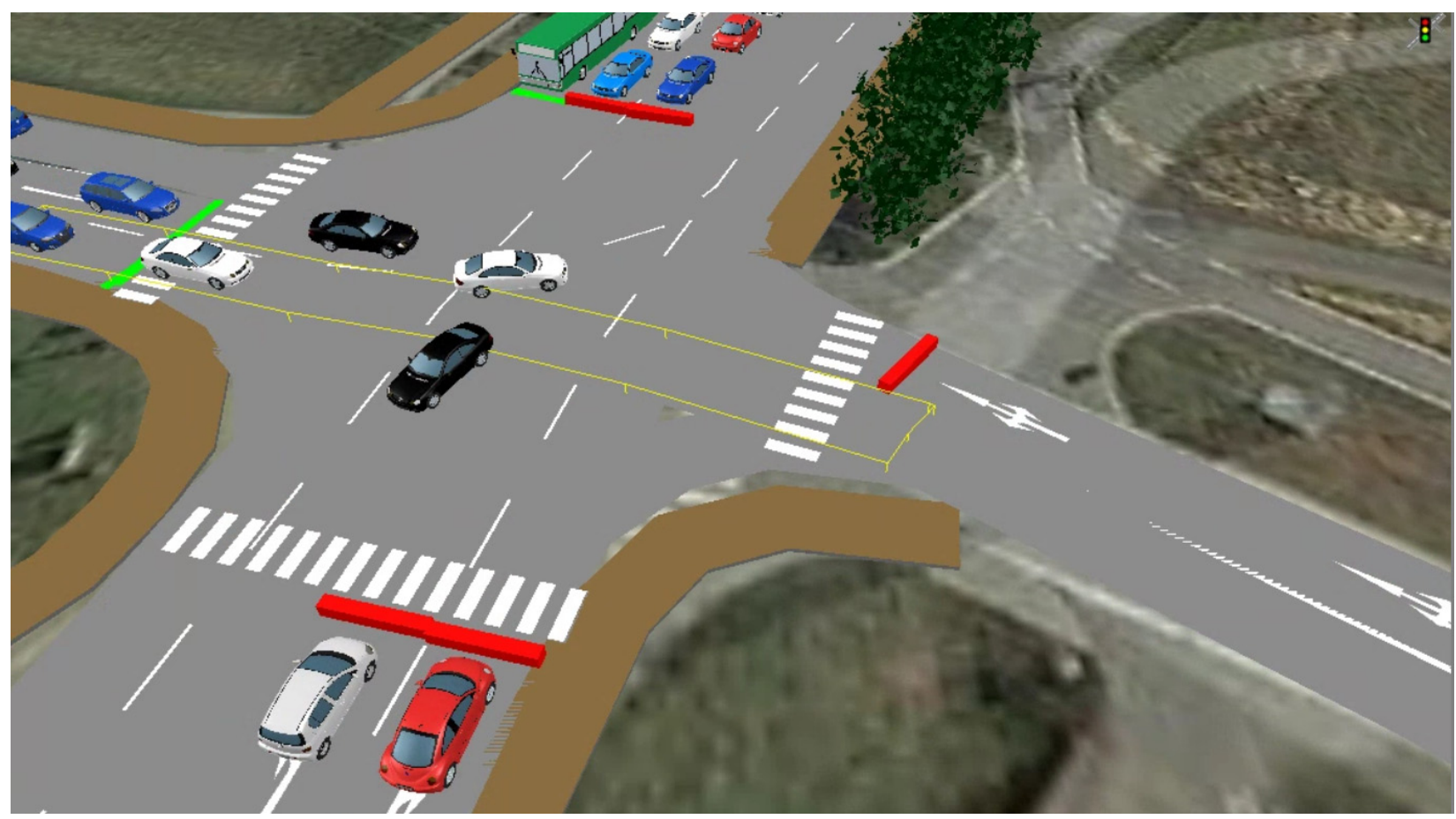

(c) overlaps the green wave from the Uherské Hradiště direction with the green wave from Staré Město

Figure 6. Model of the Hradišt'ská-Východní-Zrezavice intersection. (a) turning right from the industrial zone in the direction of Uherské Hradiště (when the green line is on); (b) downtime in turning from the direction Staré Město toward the commercial and industrial zone; (c) overlaps the green wave from the Uherské Hradiště direction with the green wave from Staré Město.

Table 3. Numbers of vehicles and vehicle travel time-current state.

\begin{tabular}{ccccccc}
\hline Direction & \multicolumn{2}{c}{ A-B } & \multicolumn{2}{c}{ B-C } & \multicolumn{2}{c}{ C-B } \\
\hline $\begin{array}{c}\text { Simulation } \\
\text { Time (s) }\end{array}$ & $\begin{array}{c}\text { Number } \\
\text { of } \\
\text { Vehicles }\end{array}$ & $\begin{array}{c}\text { Vehicle } \\
\text { Travel } \\
\text { Time (s) }\end{array}$ & $\begin{array}{c}\text { Number } \\
\text { of } \\
\text { Vehicles }\end{array}$ & $\begin{array}{c}\text { Vehicle } \\
\text { Travel } \\
\text { Time (s) }\end{array}$ & $\begin{array}{c}\text { Number } \\
\text { of } \\
\text { Vehicles }\end{array}$ & $\begin{array}{c}\text { Vehicle } \\
\text { Travel } \\
\text { Time (s) }\end{array}$ \\
\hline $0-900$ & 383 & 34.73 & 214 & 24.74 & 169 & 68.57 \\
$900-1800$ & 409 & 33.22 & 227 & 26.08 & 176 & 67.34 \\
$1800-2700$ & 314 & 40.70 & 213 & 26.27 & 176 & 71.92 \\
$2700-3600$ & 332 & 41.27 & 215 & 25.18 & 157 & 67.32 \\
Average & 359.5 & 37.50 & 217.25 & 25.57 & 169.5 & 68.80 \\
Minimum & 314 & 33.22 & 213 & 24.74 & 157 & 67.32 \\
Maximum & 409 & 41.27 & 227 & 26.27 & 176 & 71.92 \\
\hline
\end{tabular}

Table 4. Numbers of vehicles and vehicle travel time—changing route from Staré Město.

\begin{tabular}{ccccccc}
\hline Direction & \multicolumn{2}{c}{ A-B } & \multicolumn{2}{c}{ B-C } & \multicolumn{2}{c}{ C-B } \\
\hline $\begin{array}{c}\text { Simulation } \\
\text { Time (s) }\end{array}$ & $\begin{array}{c}\text { Number } \\
\text { of } \\
\text { Vehicles }\end{array}$ & $\begin{array}{c}\text { Vehicle } \\
\text { Travel } \\
\text { Time (s) }\end{array}$ & $\begin{array}{c}\text { Number } \\
\text { of } \\
\text { Vehicles }\end{array}$ & $\begin{array}{c}\text { Vehicle } \\
\text { Travel } \\
\text { Time (s) }\end{array}$ & $\begin{array}{c}\text { Number } \\
\text { of } \\
\text { Vehicles }\end{array}$ & $\begin{array}{c}\text { Vehicle } \\
\text { Travel } \\
\text { Time (s) }\end{array}$ \\
\hline $0-900$ & 543 & 25.19 & 219 & 22.22 & 187 & 58.10 \\
$900-1800$ & 553 & 25.18 & 252 & 22.48 & 203 & 61.70 \\
$1800-2700$ & 587 & 25.41 & 222 & 24.51 & 168 & 60.54 \\
$2700-3600$ & 562 & 25.91 & 244 & 22.66 & 198 & 58.47 \\
Average & 561.3 & 25.40 & 234.3 & 23.00 & 189 & 59.70 \\
Minimum & 553 & 25.18 & 219 & 22.22 & 187 & 58.10 \\
Maximum & 562 & 25.91 & 222 & 24.51 & 203 & 61.70 \\
\hline
\end{tabular}


Table 5. Numbers of vehicles and vehicle travel time-modified traffic lights.

\begin{tabular}{ccccccc}
\hline Direction & \multicolumn{2}{c}{ A-B } & \multicolumn{2}{c}{ B-C } & \multicolumn{2}{c}{ C-B } \\
\hline $\begin{array}{c}\text { Simulation } \\
\text { Time (s) }\end{array}$ & $\begin{array}{c}\text { Number } \\
\text { of } \\
\text { Vehicles }\end{array}$ & $\begin{array}{c}\text { Vehicle } \\
\text { Travel } \\
\text { Time (s) }\end{array}$ & $\begin{array}{c}\text { Number } \\
\text { of } \\
\text { Vehicles }\end{array}$ & $\begin{array}{c}\text { Vehicle } \\
\text { Travel } \\
\text { Time (s) }\end{array}$ & $\begin{array}{c}\text { Number } \\
\text { of } \\
\text { Vehicles }\end{array}$ & $\begin{array}{c}\text { Vehicle } \\
\text { Travel } \\
\text { Time (s) }\end{array}$ \\
\hline $0-900$ & 366 & 35.80 & 215 & 24.52 & 170 & 66.33 \\
900-1800 & 393 & 34.49 & 233 & 24.47 & 194 & 64.12 \\
1800-2700 & 330 & 39.92 & 211 & 25.29 & 179 & 64.24 \\
2700-3600 & 359 & 41.66 & 228 & 23.85 & 201 & 63.27 \\
Average & 362 & 38.00 & 221.8 & 24.50 & 186 & 64.50 \\
Minimum & 393 & 34.49 & 228 & 23.85 & 201 & 63.27 \\
Maximum & 359 & 41.66 & 211 & 25.29 & 170 & 66.33 \\
\hline
\end{tabular}

This structure of results allows variants to be compared, taking into account the lengths of congestion in each direction (Figure 7) and the vehicle delay (Figure 8).

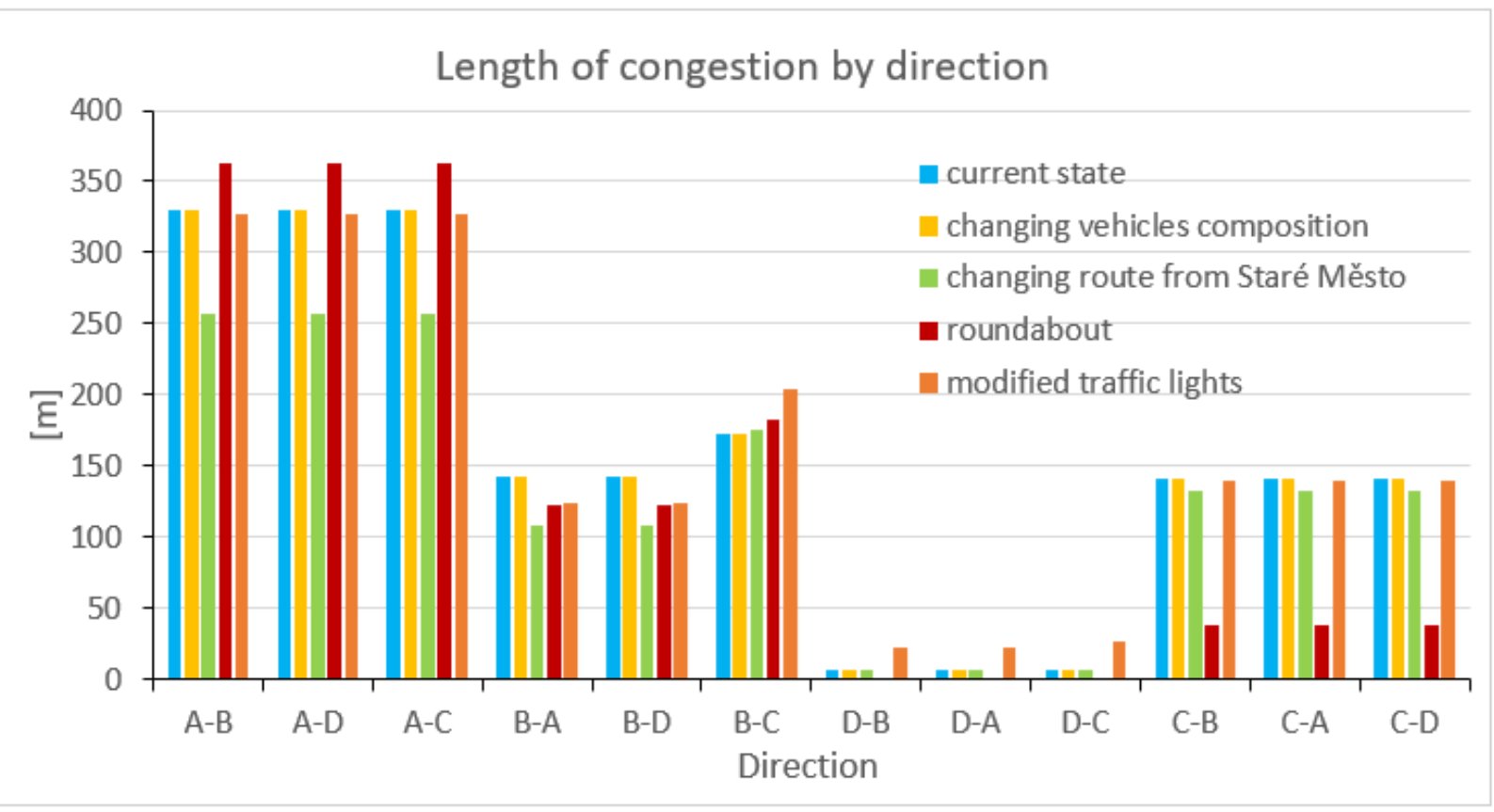

Figure 7. Length of congestion by direction.

The results of simulation experiments for alternative solutions were realized based on data sets that most concisely characterized the undesirable condition at the transport node-traffic congestion. First of all, the length of columns in all directions was monitored. This indicator presents the capacity of traffic directions. The next indicator was the time of the vehicles' passage through the transport hub. It was another set of data describing whether the vehicles would not pass slowly within the individual variants, which would have bad environmental impacts. The final monitored indicator was the delay of vehicles at the intersection. It was the time that included, in addition to driving time, the waiting of vehicles at a transport hub due to traffic congestion. 


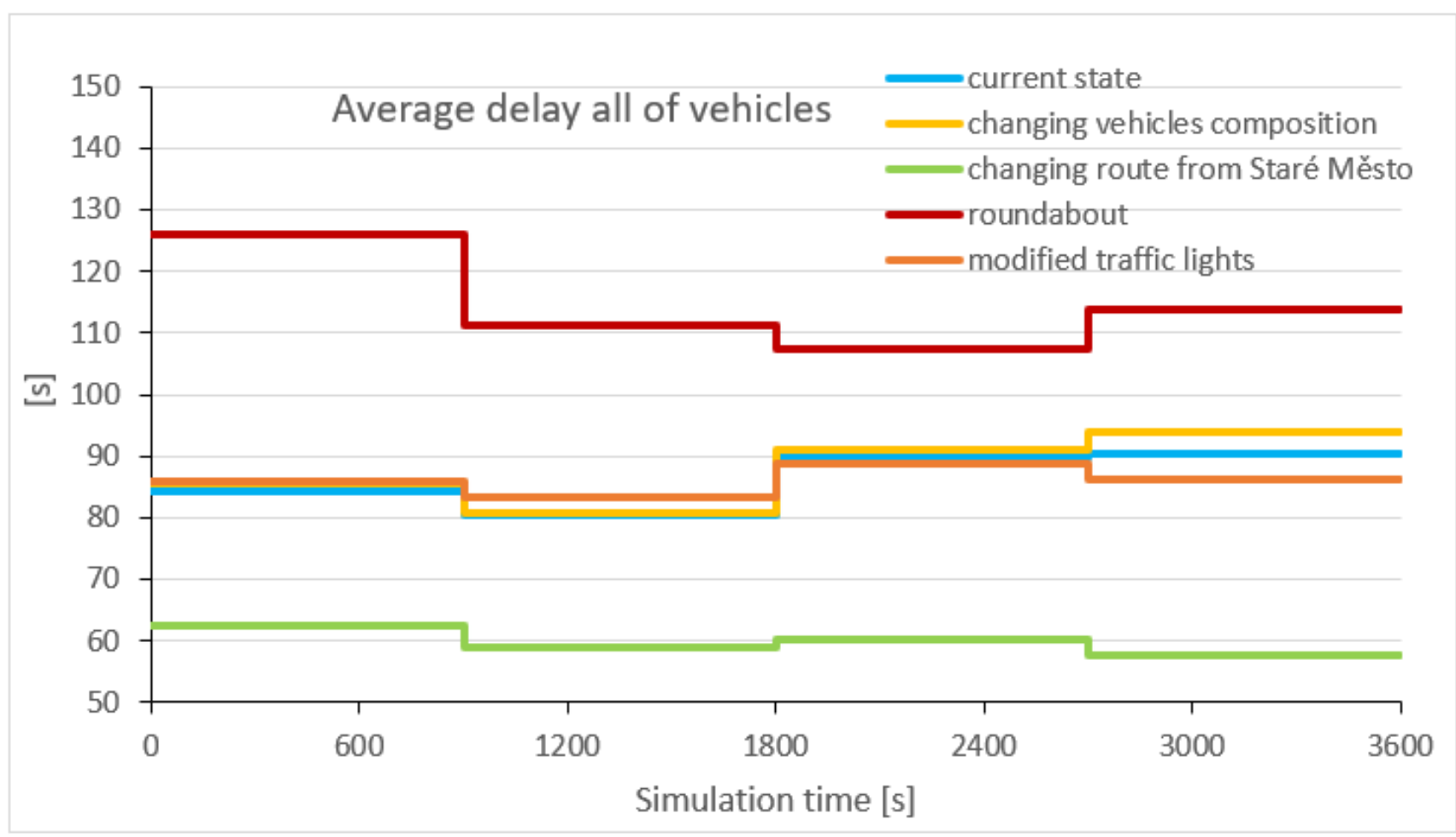

Figure 8. Average delay of all vehicles.

\section{Discussion}

To provide a comprehensive solution and comparison of individual alternatives, four independent microscopic simulation models were created. Subsequently, careful simulation experiments were implemented and the results were then compared. The key objective was to derive a solution that represented a substantial improvement compared to the existing, uncomfortable situation of the transport process.

\subsection{The Experiment of Changing the Composition of Vehicles}

This experiment consists of excluding lorries from the intersection. Lorries can use a bypass without slowing down the traffic in this prominent hub. The model preserved random numbers of buses because the exact numbers were not the subject of the research. During the simulation, 4638 vehicles passed through the traffic hub, which was 126 vehicles greater than in the existing state. The transit time of vehicles when excluding lorries did not exceed $25 \mathrm{~s}$ for 218 vehicles. Compared to the existing state, there was a slight difference. The main difference in the transit time and the number of vehicles coming from the commercial zone to Uherské Hradiště compared to the current state is that an additional 15 vehicles can pass through the specific segment within the approximate same period. The transit from Staré Město to Uherské Hradiště upon excluding lorries is not significantly influenced, which means that there is no major difference compared to the current state. Tailbacks in individual directions are usually longer than in the default state of the intersection. The average delay of cars at the traffic hub approximately equals that of the basic model, with the difference not exceeding $7 \mathrm{~s}$ of delay within one hour's simulation.

\subsection{Changing the Route from Staré Město Direction}

This experiment focuses on vehicles turning toward commercial centers in the direction of Staré Město. At this traffic hub, it means that this direction will no longer provide the possibility of turning toward the commercial zone. The only possible ways are to go straight or turn toward the quay. Vehicles traveling to the commercial zone must turn onto Huštěnovská Street at the previous junction and then take the direction to Luční District. As a result, the overall traffic capacity increased by 958 vehicles compared to 
the default state. In comparison to the current state, the amount of emissions produced was reduced by $23 \%$ after re-calculating the ratio of passing vehicles and the quantity of emissions. Because this experiment excluded turning left from the Staré Město direction, the light signalization was modified, which resulted in a shorter transit time in the given directions and an increase in several vehicles passing through this segment. As contrasted with the basic model simulation, in the model with changed composition, approximately 20 more vehicles were able to pass in the $\mathrm{C}-\mathrm{B}$ direction in a shorter transit time. The most significant change occurred in vehicles transiting in the A-B direction, where the number of passing vehicles increased from the original 360 to 561 and the transit time was reduced to $12 \mathrm{~s}$. This represents an improvement of $62.5 \%$ after the total period was calculated. The tailback from the Staré Město direction was considerably shorter than in the original situation. Other directions did not see such a large difference. Overall, we may argue that the situation at the traffic hub improved because the overall delay at the intersection dropped from 344.5 to $239.45 \mathrm{~s}$ within one hour of the simulation. After re-calculating, the interval fell from $86 \mathrm{~s}$ to approximately $60 \mathrm{~s}$.

\subsection{Implementing a Roundabout}

In this experiment, the construction and type of the intersection were changed to a two-lane roundabout (Figure 9). During the design, a minimal roundabout inner diameter of $5.3 \mathrm{~m}$ was preserved; the outer diameter was $25 \mathrm{~m}$, which enables a smooth transit of longer semi-trailers.

The number of vehicles that passed through the given intersection within one hour's simulation equaled 545. The total amount of emissions that were released into the atmosphere during the simulation process decreased. Nonetheless, after re-calculating the emissions concerning the total amount of vehicles that had passed through the given segment, this ratio increased by $19.36 \%$ compared to the current state.

The transit time of vehicles from Uherské Hradiště to the commercial zone suggested significantly increased compared to the basic model. By contrast, upon implementing the roundabout, the transit time from the commercial zone decreased and the traffic capacity from the respective zone expanded. The vehicles heading to Uherské Hradiště passed through within $46 \mathrm{~s}$ on average. However, vehicles coming from Staré Město experienced an increased transit time in this experiment. Tailbacks in separate directions after implementing the roundabout and in the current state were approximately equal; however, the tailback from the commercial-industrial zone was reduced by $72 \%$.

\subsection{Changing the Cycle and Type of Light Signalization}

Another possible solution focused on modifying the light signalization at the traffic hub. The cycle of $65 \mathrm{~s}$ was preserved, and the alternatives for turning from the quay and commercial zone were added. The green interval from the $\mathrm{C}$ direction was changed from $18 \mathrm{~s}$ to $16 \mathrm{~s}$. The green for the quay and commercial zone did not start at the same time- the green for the commercial zone was delayed by $2 \mathrm{~s}$.

After modifying the light signalization, 4649 vehicles passed through the specific intersection; i.e., 137 vehicles more than in the current state. The transit of vehicles in the $\mathrm{B}-\mathrm{C}$ direction improved by $1 \mathrm{~s}$ on average and the traffic capacity expanded by four vehicles. The transit time from the commercial zone was reduced, which resulted in a larger number of vehicles passing through the given traffic hub compared to the default setting of the light signalization. The same applied to the transit time of vehicles from Staré Město. The length of congestion was approximately equal; the only significant difference was from the quay direction, with a tailback $27 \mathrm{~m}$ long compared to the current $6 \mathrm{~m}$. The waiting time at the traffic hub was roughly the same as in the default state even in Experiment 3. Vehicles wait a maximum of 89 s; i.e., $1.5 \mathrm{~s}$ more than before. 


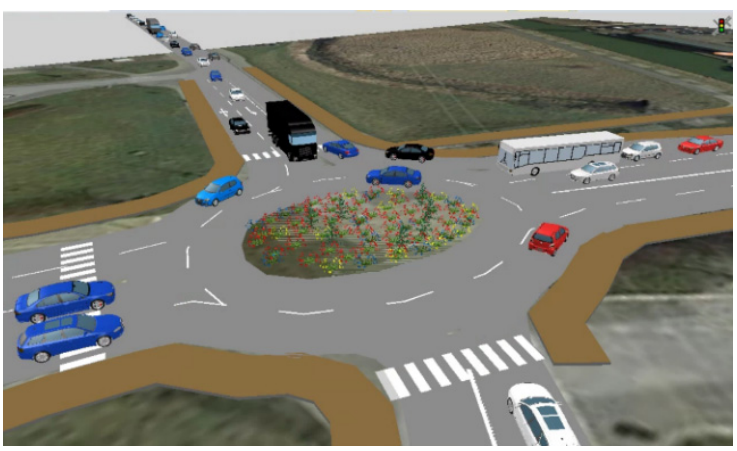

(a) view on the two-lane roundabout from the direction of industrial zone

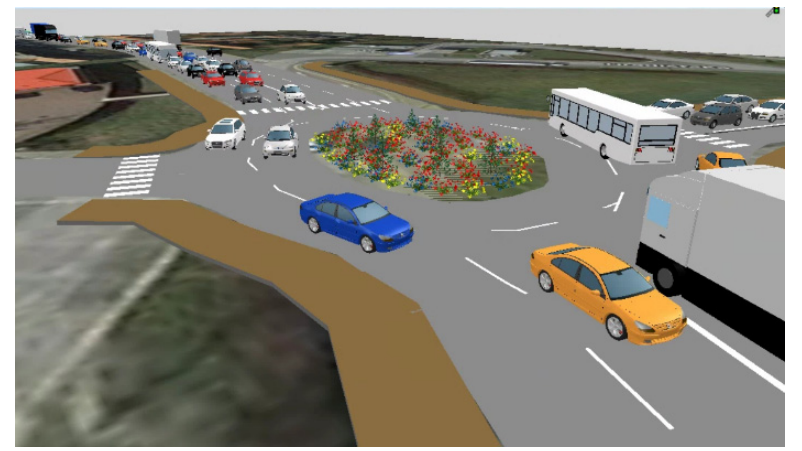

(b) view on the two-lane roundabout to the direction of the Staré Město

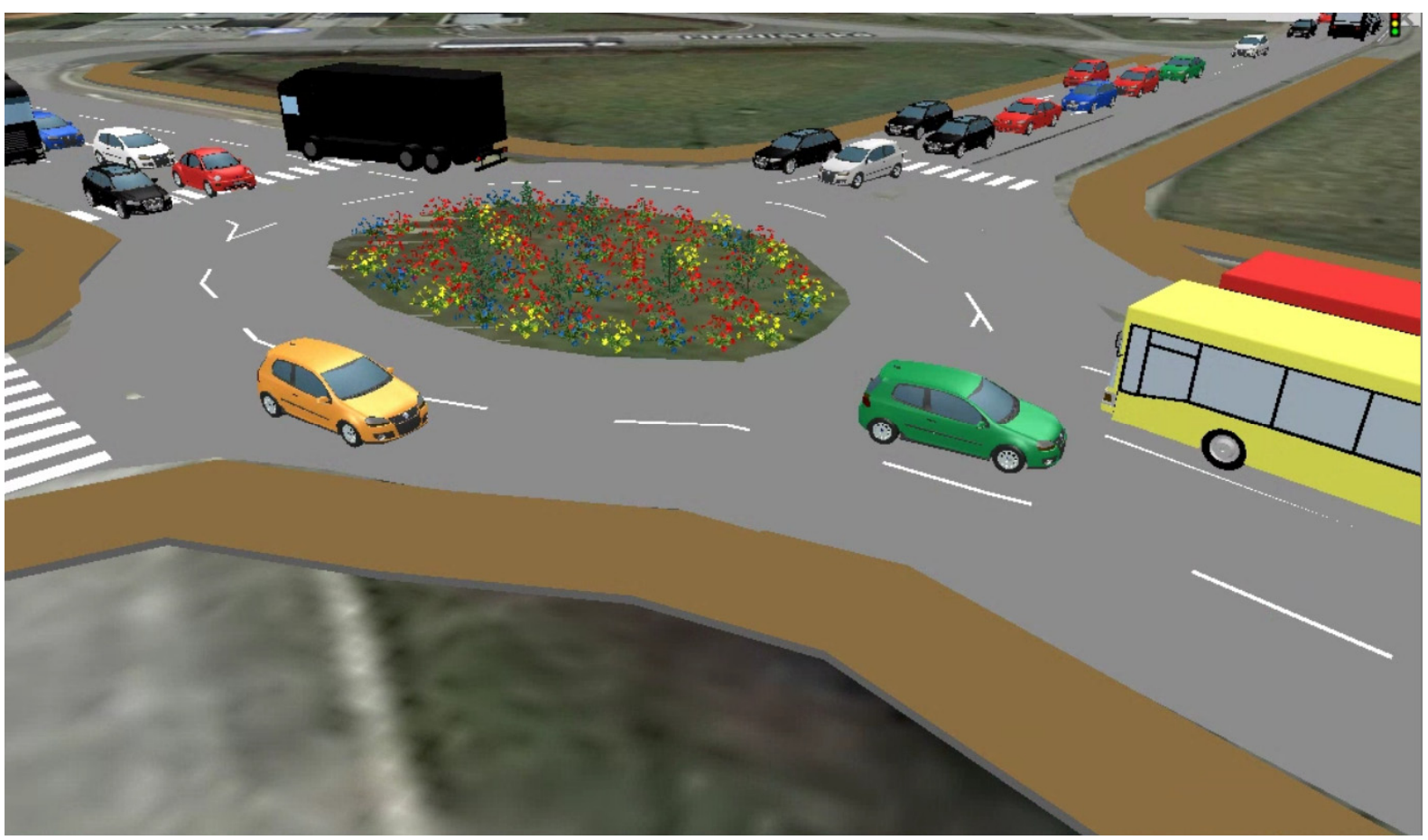

(c) view on the two-lane roundabout to the direction of Uherské Hradiště

Figure 9. Model of the roundabout. (a) view on the two-lane roundabout from the direction of industrial zone; (b) view on the two-lane roundabout to the direction of the Staré Město; (c) view on the two-lane roundabout to the direction of Uherské Hradiště.

\subsection{Evaluation of Experiments}

The results of simulation experiments provide a wide range of information that characterizes in detail the individual variants designed to ensure the sustainability of transport in a given urban area. Figure 10 presents an example of part of the obtained results.

From the results, it is necessary to choose the optimal solution based on the obtained parameters. Because the comparison is based on several criteria, it is appropriate in this case to apply the method of multi-criteria decision-making.

There are currently a large number of multi-criteria decision-making methods. One of these methods is the analytical hierarchy process (AHP). AHP is a structured technique used to solve complex decisions. It is based on mathematical procedures and human psychology [35]. AHP provides a complex and logical concept for structuring a problem, quantifying its elements that are related to the overall objectives and evaluating alternative solutions. From the factors that make the AHP perhaps the most popular decision-making method, it can be emphasized that it adapts to fixed data, such as the speed of delivery, 
price, and personal experiences [36]. It allows mathematical derivation of the weight of criteria, instead of the subjective selection of criteria weights, as used by other decisionmaking methods [37].
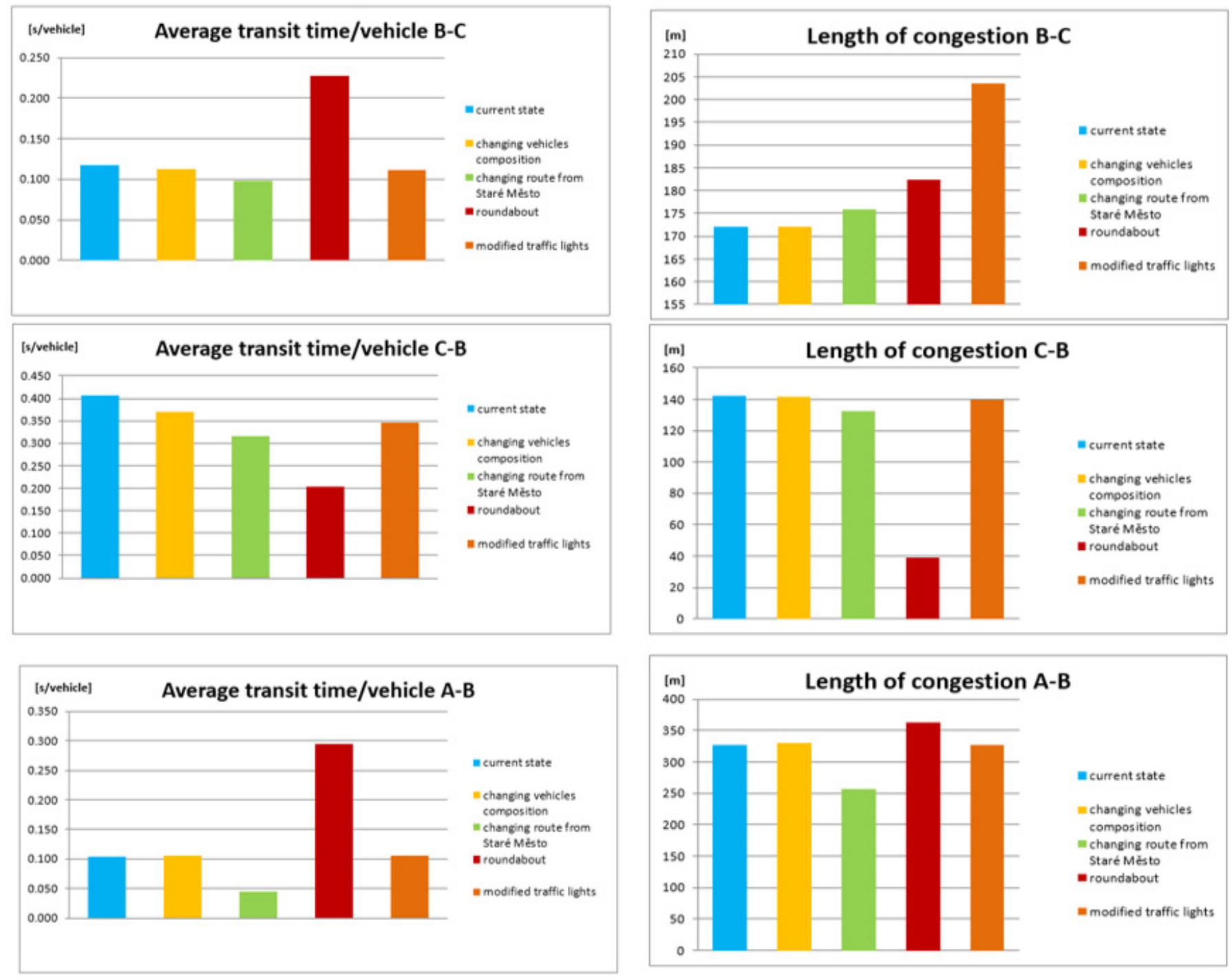

Figure 10. Transit time and congestion length.

Several studies have used AHP for the solution of transport problems in the direction of sustainability and environmental impact; for example, using AHP for the development of a decision support framework to assess quantitative risk in multimodal green logistics [38]; the multiple criteria decision-making approach for route selection in the multimodal supply chain, which is based on the combination of AHP, data envelopment analysis (DEA), and the techniques for the order of preference by similarity to ideal solution (TOPSIS) [39]; and the evaluation and diagnosis of urban streets using an integrated multi-criteria model of a sustainable nature [31].

Based on published research, this method has good preconditions for its use in combination with the computer simulation method.

The model of AHP was created for comparison of variants of transport sustainability on the basis of the results of simulation experiments. The basic structure is presented in Figure 11. 


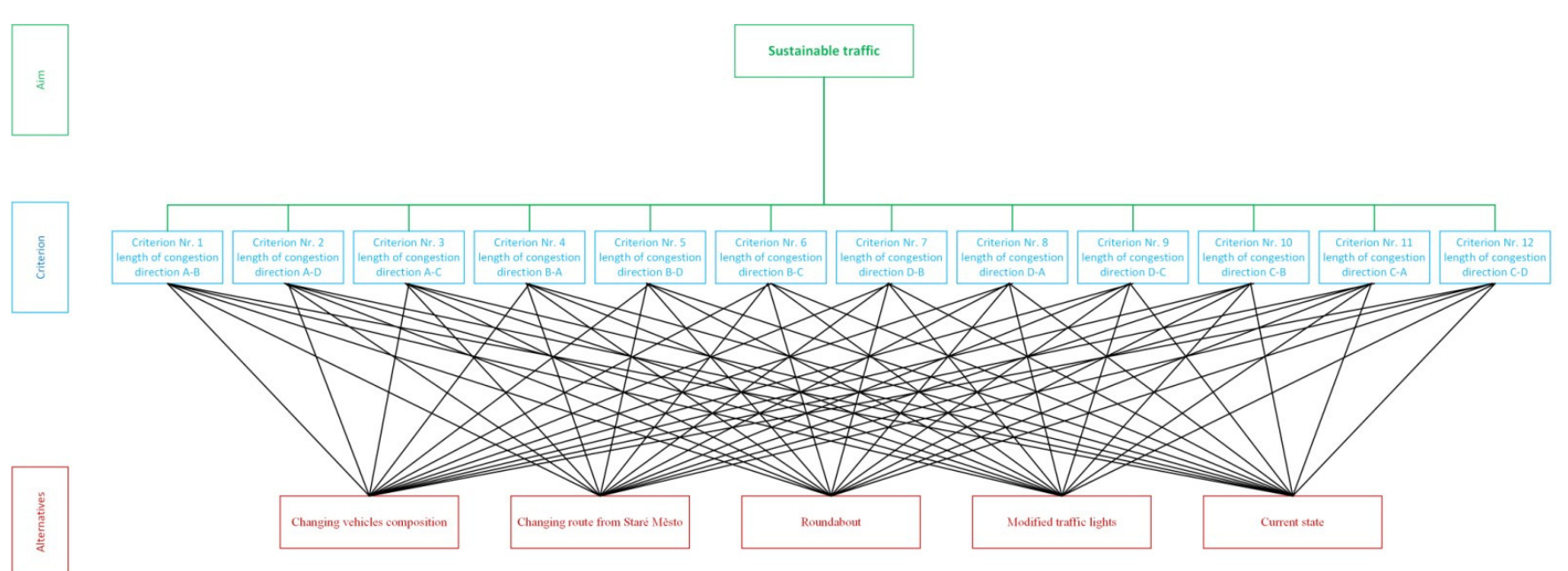

Figure 11. The structure of the analytical hierarchy process (AHP) model.

The structure of the proposed AHP model consists of three hierarchical levels. At the highest level is the goal of choosing a suitable solution for the needs of transport sustainability. Its achievement is realized based on 12 criteria, which were based on traffic directions connected with the analyzed transport hub. The aforementioned 12 criteria form the second level of the model. The third level of the model is represented by individual alternatives, which were part of the realized simulation experiments.

The evaluation criteria and the determination of their weights was realized by a group of experts. The role of this group was to help determine the weights of the criteria, to determine the weights of the objectives, to organize the objectives, and to determine the weights of the decision criteria. It must be said that the selection of the evaluation criteria and their weights was based on published knowledge $[40,41]$. Experts were selected so that their evaluation was considered objective. We tried to achieve this by concentrating several specialists from areas that are related to the problem of the transport hub and its operation.

The criterion of the competence of the experts was their professional knowledge, knowledge of the transport hub in terms of its operation and its impact on the environment. The experts have more than 10 years of experience in the researched issue. The structure of the experts is presented in Table 6.

Table 6. The criterion of the competence of the experts.

\begin{tabular}{|c|c|c|c|c|}
\hline & Expert & $\begin{array}{c}\text { Experiences } \\
\text { Practical }\end{array}$ & $\begin{array}{l}\text { Experiences } \\
\text { Theoretical }\end{array}$ & Male/Female \\
\hline 1. & The expert from the field of transport & $2-5 y$ & more than $10 \mathrm{y}$ & was not considered \\
\hline 2. & Residents living near the transport hub & $2-5 y$ & - & $50 / 50$ \\
\hline 3. & Public transport drivers passing through a hub & $0.5-1 \mathrm{y}$ & more than $10 \mathrm{y}$ & was not considered \\
\hline 4. & Drivers of vehicles supplying operations in the area & $0.5-1 \mathrm{y}$ & more than $10 \mathrm{y}$ & was not considered \\
\hline 5. & People working in the area & $0.5-1 \mathrm{y}$ & more than $10 \mathrm{y}$ & $50 / 50$ \\
\hline 6. & Persons passing through a transport hub & $0.25-0.5 y$ & - & $50 / 50$ \\
\hline
\end{tabular}

y means years.

The individual directions at the transport hub were chosen as criteria. These criteria made it possible to evaluate the individual variants. Criteria that represent the directions of traffic that directly affect the traffic situation at the main nodes have higher weight than the directions that provide the diversion of traffic to areas that are adjacent to the traffic hub and are located on commercial premises and residential blocks. The definition of weights (Table 7) was based on the recommendation published in [35]. 
Table 7. The definition of weights.

\begin{tabular}{ccc}
\hline Intensity of Importance & Definition & Explanation \\
\hline 1 & $\begin{array}{c}\text { Equal importance } \\
\text { Less importance of one variant } \\
\text { compared to another } \\
\text { Substantial or strong } \\
\text { importance } \\
5\end{array}$ & $\begin{array}{c}\text { Two variants are also involved in the intervention of the goals. } \\
\text { Experience and opinions gently prefer one attribute } \\
\text { over another. }\end{array}$ \\
9 & $\begin{array}{c}\text { Demonstrable importance } \\
\text { Experience and opinions strongly prefer one attribute } \\
\text { over another. }\end{array}$ & $\begin{array}{c}\text { One attribute is highly preferred, and its dominance is } \\
\text { demonstrated in practice. }\end{array}$ \\
$2,4,6,8$ & $\begin{array}{c}\text { Absolute importance } \\
\text { Mean values between two } \\
\text { adjacent variants }\end{array}$ & $\begin{array}{c}\text { The obvious favoring of one attribute over another is at the } \\
\text { highest possible level of expression. } \\
\text { A compromise is needed due to the ambiguity of the } \\
\text { assignment in relation to the above definitions of importance. }\end{array}$ \\
\hline
\end{tabular}

We used three options for the selection of the method to evaluate the criteria. It was specifically about brainwriting, brainstorming, and the Delphic method. This selection was realized on the basis of the selected literature review, for example [42] and [43]. Based on the above facts, the brainwriting method was chosen. The main reason was the fact that it was possible to harmonize the selected experts to negate their fear of expressing their views in public, and this method made it possible to address that [44]. Brainwriting is a method that is suitable to use in the case that we assume that some participants may be shy in expressing their ideas [45]. It is a method that, in contrast to brainstorming, can effectively involve all its participants and, as a result, often offers more options [45]. The comparison of individual methods and their possibilities of use within AHP is offered by $[42,43]$.

The evaluation of criteria in terms of significance is shown in Table 8. In their evaluation, the impact of individual roads on the creation of traffic congestion was taken into account.

Table 8. Evaluation of criteria in term of significance.

\begin{tabular}{|c|c|c|c|c|c|c|c|c|c|c|c|c|}
\hline $\begin{array}{c}\text { Criteria } \\
\text { Preferences }\end{array}$ & $\begin{array}{c}\text { K1 } \\
\text { Route } \\
\text { A-B }\end{array}$ & $\begin{array}{c}\text { K2 } \\
\text { Route } \\
\text { A-D }\end{array}$ & $\begin{array}{c}\text { K3 } \\
\text { Route } \\
\text { A-C }\end{array}$ & $\begin{array}{c}\text { K4 } \\
\text { Route } \\
\text { B-A }\end{array}$ & $\begin{array}{c}\text { K5 } \\
\text { Route } \\
\text { B-D }\end{array}$ & $\begin{array}{c}\text { K6 } \\
\text { Route } \\
\text { B-C }\end{array}$ & $\begin{array}{c}\text { K7 } \\
\text { Route } \\
\text { D-B }\end{array}$ & $\begin{array}{c}\text { K8 } \\
\text { Route } \\
\text { D-A }\end{array}$ & $\begin{array}{c}\text { K9 } \\
\text { Route } \\
\text { D-C }\end{array}$ & $\begin{array}{c}\text { K10 } \\
\text { Route } \\
\text { C-B }\end{array}$ & $\begin{array}{c}\text { K11 } \\
\text { Route } \\
\text { C-A }\end{array}$ & $\begin{array}{c}\text { K12 } \\
\text { Route } \\
\text { C-D }\end{array}$ \\
\hline K1 Route A-B & 1 & 5 & 3 & 8 & 6 & 7 & 6 & 8 & 9 & 7 & 6 & 9 \\
\hline K2 Route A-D & $1 / 5$ & 1 & 2 & $1 / 6$ & 3 & $1 / 2$ & $1 / 5$ & $1 / 4$ & 8 & $1 / 5$ & 4 & 3 \\
\hline K3 Route A-C & $1 / 3$ & $1 / 2$ & 1 & $1 / 7$ & 5 & 6 & $1 / 7$ & $1 / 6$ & 6 & 3 & 4 & 5 \\
\hline K4 Route B-A & $1 / 8$ & 6 & 7 & 1 & 7 & 5 & 4 & 8 & 8 & $1 / 6$ & 5 & 8 \\
\hline K5 Route B-D & $1 / 6$ & $1 / 3$ & $1 / 5$ & $1 / 7$ & 1 & $1 / 3$ & $1 / 6$ & $1 / 4$ & 5 & $1 / 4$ & $1 / 7$ & 6 \\
\hline K6 Route B-C & $1 / 7$ & 2 & $1 / 6$ & $1 / 5$ & 3 & 1 & $1 / 6$ & $1 / 7$ & 3 & $1 / 5$ & $1 / 7$ & 5 \\
\hline K7 Route D-B & $1 / 6$ & 5 & 7 & $1 / 4$ & 6 & 6 & 1 & 5 & 5 & 3 & 5 & 5 \\
\hline K8 Route D-A & $1 / 8$ & 4 & 6 & $1 / 8$ & 4 & 7 & $1 / 5$ & 1 & $1 / 6$ & $1 / 7$ & $1 / 3$ & 5 \\
\hline K9 Route D-C & $1 / 9$ & $1 / 8$ & $1 / 6$ & $1 / 8$ & $1 / 5$ & $1 / 3$ & $1 / 5$ & 6 & 1 & $1 / 6$ & $1 / 6$ & $1 / 2$ \\
\hline K10 Route C-B & $1 / 7$ & 5 & $1 / 3$ & 6 & 4 & 5 & $1 / 3$ & 7 & 6 & 1 & 7 & 7 \\
\hline K11 Route C-A & $1 / 6$ & $1 / 4$ & $1 / 4$ & $1 / 5$ & 7 & 7 & $1 / 5$ & 3 & 6 & $1 / 7$ & 1 & 8 \\
\hline K12 Route C-D & $1 / 9$ & $1 / 3$ & $1 / 5$ & $1 / 8$ & $1 / 6$ & $1 / 5$ & $1 / 5$ & $1 / 5$ & 2 & $1 / 7$ & $1 / 8$ & 1 \\
\hline
\end{tabular}

In the next step, a pairwise comparison of the alternative solutions considered in the context of individual criteria was realized (Table 9). In this comparison, the lengths of traffic congestion were taken into account, which were identified in the implementation of simulation experiments. This means that based on routes (criteria), variants were evaluated and compared with each other. The lower the length of the traffic congestion, the higher the rating assigned to the alternative. At the same time, the principle of universal axiom was observed. This created a reciprocal matrix in which all elements on the main diagonal were equal to 1 . 
Table 9. Pairwise comparison of alternative solutions.

\begin{tabular}{|c|c|c|c|c|c|}
\hline K1 Route A-B & $\begin{array}{l}\text { Changing Vehicle } \\
\text { Composition }\end{array}$ & $\begin{array}{l}\text { Changing Route } \\
\text { from Staré Město }\end{array}$ & Roundabout & $\begin{array}{c}\text { Modified Traffic } \\
\text { Lights }\end{array}$ & $\begin{array}{l}\text { Current } \\
\text { State }\end{array}$ \\
\hline $\begin{array}{l}\text { Changing vehicle } \\
\text { composition }\end{array}$ & 1 & $1 / 8$ & 6 & $1 / 2$ & $1 / 4$ \\
\hline $\begin{array}{l}\text { Changing route from } \\
\text { Staré Město }\end{array}$ & 8 & 1 & 9 & 7 & 5 \\
\hline Roundabout & $1 / 6$ & $1 / 9$ & 1 & $1 / 3$ & $1 / 4$ \\
\hline Modified traffic lights & 2 & $1 / 7$ & 3 & 1 & $1 / 2$ \\
\hline Current state & 4 & $1 / 5$ & 4 & 2 & 1 \\
\hline \multicolumn{2}{|c|}{ CI: 0.1151} & \multicolumn{2}{|c|}{ CR: 0.1037} & \multicolumn{2}{|c|}{$\lambda: 5.4606$} \\
\hline K2 Route A-D & $\begin{array}{c}\text { Changing Vehicle } \\
\text { Composition }\end{array}$ & $\begin{array}{l}\text { Changing Route } \\
\text { from Staré Město }\end{array}$ & Roundabout & $\begin{array}{c}\text { Modified Traffic } \\
\text { Lights }\end{array}$ & $\begin{array}{l}\text { Current } \\
\text { State }\end{array}$ \\
\hline $\begin{array}{l}\text { Changing vehicle } \\
\text { composition }\end{array}$ & 1 & $1 / 8$ & 6 & $1 / 2$ & $1 / 4$ \\
\hline $\begin{array}{l}\text { Changing route from } \\
\text { Staré Město }\end{array}$ & 8 & 1 & 9 & 7 & 5 \\
\hline Roundabout & $1 / 6$ & $1 / 9$ & 1 & $1 / 3$ & $1 / 4$ \\
\hline Modified traffic lights & 2 & $1 / 7$ & 3 & 1 & $1 / 2$ \\
\hline Current state & 4 & $1 / 5$ & 4 & 2 & 1 \\
\hline \multicolumn{2}{|c|}{ CI: 0.1151} & \multicolumn{2}{|c|}{ CR: 0.1037} & \multicolumn{2}{|c|}{$\lambda: 5.4606$} \\
\hline K3 Route A-C & $\begin{array}{l}\text { Changing Vehicle } \\
\text { Composition }\end{array}$ & $\begin{array}{l}\text { Changing Route } \\
\text { from Staré Město }\end{array}$ & Roundabout & $\begin{array}{c}\text { Modified Traffic } \\
\text { Lights }\end{array}$ & $\begin{array}{l}\text { Current } \\
\text { State }\end{array}$ \\
\hline $\begin{array}{l}\text { Changing vehicle } \\
\text { composition }\end{array}$ & 1 & $1 / 8$ & 6 & $1 / 2$ & $1 / 4$ \\
\hline $\begin{array}{l}\text { Changing route from } \\
\text { Staré Město }\end{array}$ & 8 & 1 & 9 & 7 & 5 \\
\hline Roundabout & $1 / 6$ & $1 / 9$ & 1 & $1 / 3$ & $1 / 4$ \\
\hline Modified traffic lights & 2 & $1 / 7$ & 3 & 1 & $1 / 2$ \\
\hline Current state & 4 & $1 / 5$ & 4 & 2 & 1 \\
\hline \multicolumn{2}{|c|}{ CI: 0.1151} & \multicolumn{2}{|c|}{ CR: 0.1037} & \multicolumn{2}{|c|}{$\lambda: 5.4606$} \\
\hline K4 Route B-A & $\begin{array}{l}\text { Changing Vehicle } \\
\text { Composition }\end{array}$ & $\begin{array}{l}\text { Changing Route } \\
\text { from Staré Město }\end{array}$ & Roundabout & $\begin{array}{l}\text { Modified Traffic } \\
\text { Lights }\end{array}$ & $\begin{array}{l}\text { Current } \\
\text { State }\end{array}$ \\
\hline $\begin{array}{l}\text { Changing vehicle } \\
\text { composition }\end{array}$ & 1 & 4 & 3 & 3 & 3 \\
\hline $\begin{array}{l}\text { Changing route from } \\
\text { Staré Město }\end{array}$ & $1 / 4$ & 1 & 3 & 3 & 3 \\
\hline Roundabout & $1 / 3$ & $1 / 3$ & 1 & 2 & 3 \\
\hline Modified traffic lights & $1 / 3$ & $1 / 3$ & $1 / 2$ & 1 & 2 \\
\hline Current state & $1 / 3$ & $1 / 4$ & $1 / 3$ & $1 / 2$ & 1 \\
\hline \multicolumn{2}{|c|}{ CI: 0.1078} & \multicolumn{2}{|c|}{ CR: 0.0971} & \multicolumn{2}{|c|}{$\lambda: 5.4310$} \\
\hline K5 Route B-D & $\begin{array}{l}\text { Changing Vehicle } \\
\text { Composition }\end{array}$ & $\begin{array}{l}\text { Changing Route } \\
\text { from Staré Město }\end{array}$ & Roundabout & $\begin{array}{l}\text { Modified Traffic } \\
\text { Lights }\end{array}$ & $\begin{array}{l}\text { Current } \\
\text { State }\end{array}$ \\
\hline $\begin{array}{l}\text { Changing vehicle } \\
\text { composition }\end{array}$ & 1 & 4 & 3 & 3 & 3 \\
\hline $\begin{array}{l}\text { Changing route from } \\
\text { Staré Město }\end{array}$ & $1 / 4$ & 1 & 3 & 3 & 3 \\
\hline Roundabout & $1 / 3$ & $1 / 3$ & 1 & 2 & 3 \\
\hline Modified traffic lights & $1 / 3$ & $1 / 3$ & $1 / 2$ & 1 & 2 \\
\hline Current state & $1 / 3$ & $1 / 4$ & $1 / 3$ & $1 / 2$ & 1 \\
\hline \multicolumn{2}{|c|}{ CI: 0.1078} & \multicolumn{2}{|c|}{ CR: 0.0971} & \multicolumn{2}{|c|}{$\lambda: 5.4310$} \\
\hline
\end{tabular}


Table 9. Cont

\begin{tabular}{|c|c|c|c|c|c|}
\hline K6 Route B-C & $\begin{array}{c}\text { Changing Vehicle } \\
\text { Composition }\end{array}$ & $\begin{array}{l}\text { Changing Route } \\
\text { from Staré Město }\end{array}$ & Roundabout & $\begin{array}{c}\text { Modified Traffic } \\
\text { Lights }\end{array}$ & $\begin{array}{c}\text { Current } \\
\text { State }\end{array}$ \\
\hline $\begin{array}{l}\text { Changing vehicle } \\
\text { composition }\end{array}$ & 1 & 2 & 3 & 5 & 2 \\
\hline $\begin{array}{l}\text { Changing route from } \\
\text { Staré Město }\end{array}$ & $1 / 2$ & 1 & 2 & 6 & $1 / 2$ \\
\hline Roundabout & $1 / 3$ & $1 / 2$ & 1 & 4 & $1 / 3$ \\
\hline Modified traffic lights & $1 / 5$ & $1 / 6$ & $1 / 4$ & 1 & $1 / 6$ \\
\hline Current state & $1 / 2$ & $1 / 5$ & 4 & 2 & 1 \\
\hline \multicolumn{2}{|c|}{ CI: 0.0453} & \multicolumn{2}{|c|}{ CR: 0.0408} & \multicolumn{2}{|c|}{$\lambda: 5.1810$} \\
\hline K7 Route D-B & $\begin{array}{c}\text { Changing Vehicle } \\
\text { Composition }\end{array}$ & $\begin{array}{l}\text { Changing Route } \\
\text { from Staré Město }\end{array}$ & Roundabout & $\begin{array}{c}\text { Modified Traffic } \\
\text { Lights }\end{array}$ & $\begin{array}{c}\text { Current } \\
\text { State }\end{array}$ \\
\hline $\begin{array}{l}\text { Changing vehicle } \\
\text { composition }\end{array}$ & 1 & $1 / 2$ & $1 / 4$ & 7 & $1 / 2$ \\
\hline $\begin{array}{l}\text { Changing route from } \\
\text { Staré Město }\end{array}$ & 2 & 1 & $1 / 3$ & 8 & $1 / 3$ \\
\hline Roundabout & 4 & 3 & 1 & 9 & 6 \\
\hline Modified traffic lights & $1 / 7$ & $1 / 8$ & $1 / 9$ & 1 & $1 / 4$ \\
\hline Current state & 2 & 3 & $1 / 6$ & 4 & 1 \\
\hline \multicolumn{2}{|c|}{ CI: 0.1484} & \multicolumn{2}{|c|}{ CR: 0.1337} & \multicolumn{2}{|c|}{$\lambda: 5.5934$} \\
\hline K8 Route D-A & $\begin{array}{l}\text { Changing Vehicle } \\
\text { Composition }\end{array}$ & $\begin{array}{l}\text { Changing Route } \\
\text { from Staré Město }\end{array}$ & Roundabout & $\begin{array}{l}\text { Modified Traffic } \\
\text { Lights }\end{array}$ & $\begin{array}{c}\text { Current } \\
\text { State }\end{array}$ \\
\hline $\begin{array}{l}\text { Changing vehicle } \\
\text { composition }\end{array}$ & 1 & $1 / 2$ & $1 / 4$ & 7 & $1 / 2$ \\
\hline $\begin{array}{l}\text { Changing route from } \\
\text { Staré Město }\end{array}$ & 2 & 1 & $1 / 3$ & 8 & $1 / 3$ \\
\hline Roundabout & 4 & 3 & 1 & 9 & 6 \\
\hline Modified traffic lights & $1 / 7$ & $1 / 8$ & $1 / 9$ & 1 & $1 / 4$ \\
\hline Current state & 2 & 3 & $1 / 6$ & 4 & 1 \\
\hline \multicolumn{2}{|c|}{ CI: 0.1484} & \multicolumn{2}{|c|}{ CR: 0.1337} & \multicolumn{2}{|c|}{$\lambda: 5.5934$} \\
\hline K9 Route D-C & $\begin{array}{l}\text { Changing Vehicle } \\
\text { Composition }\end{array}$ & $\begin{array}{l}\text { Changing Route } \\
\text { from Staré Město }\end{array}$ & Roundabout & $\begin{array}{l}\text { Modified Traffic } \\
\text { Lights }\end{array}$ & $\begin{array}{c}\text { Current } \\
\text { State }\end{array}$ \\
\hline $\begin{array}{l}\text { Changing vehicle } \\
\text { composition }\end{array}$ & 1 & $1 / 2$ & $1 / 4$ & 7 & $1 / 2$ \\
\hline $\begin{array}{l}\text { Changing route from } \\
\text { Staré Město }\end{array}$ & 2 & 1 & $1 / 3$ & 8 & $1 / 3$ \\
\hline Roundabout & 4 & 3 & 1 & 9 & 6 \\
\hline Modified traffic lights & $1 / 7$ & $1 / 8$ & $1 / 9$ & 1 & $1 / 4$ \\
\hline Current state & 2 & 3 & $1 / 6$ & 4 & 1 \\
\hline \multicolumn{2}{|c|}{ CI: 0.1484} & \multicolumn{2}{|c|}{ CR: 0.1337} & \multicolumn{2}{|c|}{$\lambda: 5.5934$} \\
\hline K10 Route C-B & $\begin{array}{l}\text { Changing Vehicle } \\
\text { Composition }\end{array}$ & $\begin{array}{l}\text { Changing Route } \\
\text { from Staré Město }\end{array}$ & Roundabout & $\begin{array}{c}\text { Modified Traffic } \\
\text { Lights }\end{array}$ & $\begin{array}{c}\text { Current } \\
\text { State }\end{array}$ \\
\hline $\begin{array}{l}\text { Changing vehicle } \\
\text { composition }\end{array}$ & 1 & $1 / 3$ & $1 / 8$ & $1 / 2$ & 2 \\
\hline $\begin{array}{l}\text { Changing route from } \\
\text { Staré Město }\end{array}$ & 3 & 1 & $1 / 8$ & 3 & 4 \\
\hline Roundabout & 8 & 8 & 1 & 8 & 9 \\
\hline Modified traffic lights & 2 & $1 / 3$ & $1 / 8$ & 1 & 3 \\
\hline Current state & $1 / 2$ & $1 / 4$ & $1 / 9$ & $1 / 3$ & 1 \\
\hline \multicolumn{2}{|c|}{ CI: 0.0742} & \multicolumn{2}{|c|}{ CR: 0.0669} & \multicolumn{2}{|c|}{$\lambda: 5.2970$} \\
\hline
\end{tabular}


Table 9. Cont

\begin{tabular}{|c|c|c|c|c|c|}
\hline K11 Route C-A & $\begin{array}{c}\text { Changing Vehicle } \\
\text { Composition }\end{array}$ & $\begin{array}{l}\text { Changing Route } \\
\text { from Staré Město }\end{array}$ & Roundabout & $\begin{array}{c}\text { Modified Traffic } \\
\text { Lights }\end{array}$ & $\begin{array}{c}\text { Current } \\
\text { State }\end{array}$ \\
\hline $\begin{array}{l}\text { Changing vehicle } \\
\text { composition }\end{array}$ & 1 & $1 / 3$ & $1 / 8$ & $1 / 2$ & 2 \\
\hline $\begin{array}{l}\text { Changing route from } \\
\text { Staré Město }\end{array}$ & 3 & 1 & $1 / 8$ & 3 & 4 \\
\hline Roundabout & 8 & 8 & 1 & $1 / 8$ & $1 / 9$ \\
\hline Modified traffic lights & 2 & $1 / 3$ & 8 & 1 & 3 \\
\hline Current state & $1 / 2$ & $1 / 4$ & 9 & $1 / 3$ & 1 \\
\hline \multicolumn{2}{|c|}{ CI: 1.4521} & \multicolumn{2}{|c|}{ CR: 1.3082} & \multicolumn{2}{|c|}{$\lambda: 10.8085$} \\
\hline K12 Route C-D & $\begin{array}{c}\text { Changing Vehicle } \\
\text { Composition }\end{array}$ & $\begin{array}{l}\text { Changing Route } \\
\text { from Staré Město }\end{array}$ & Roundabout & $\begin{array}{c}\text { Modified Traffic } \\
\text { Lights }\end{array}$ & $\begin{array}{c}\text { Current } \\
\text { State }\end{array}$ \\
\hline $\begin{array}{l}\text { Changing vehicle } \\
\text { composition }\end{array}$ & 1 & $1 / 3$ & $1 / 8$ & $1 / 2$ & 2 \\
\hline $\begin{array}{l}\text { Changing route from } \\
\text { Staré Město }\end{array}$ & 3 & 1 & $1 / 8$ & 3 & 4 \\
\hline Roundabout & 8 & 8 & 1 & 8 & 9 \\
\hline Modified traffic lights & 2 & $1 / 3$ & $1 / 8$ & 1 & $1 / 3$ \\
\hline Current state & $1 / 2$ & $1 / 4$ & $1 / 9$ & 3 & 1 \\
\hline \multicolumn{2}{|c|}{ CI: 0.1614} & \multicolumn{2}{|c|}{ CR: 0.1454} & \multicolumn{2}{|c|}{$\lambda: 5.6464$} \\
\hline
\end{tabular}

The basic scale of pairwise comparison was used in the comparison. In total, 12 pairwise comparisons were created according to the criteria. In addition to alternative proposals, the existing current situation at a researched transport hub was also included in the pairwise comparison. The aim was to avoid a situation in which none of the compared solutions was worse than the current situation.

The study used values that were the result of simulation experiments. Specifically, it was the length of traffic congestion on individual traffic directions. These characterized the number of means of transport on a given track profile. As another value, the transit time of the given section was used, which was used to monitor how favorable the given transport solution was. The application of these values in the evaluation was able to compare the individual sections and remove any advantage because the section is less frequent in terms of its importance. The value of consistency ratio (CR): 0.0933 . The main limit in the analysis is the capacity of the transport infrastructure. We speculated, excepting the roundabout, about the use of the existing transport infrastructure, without increasing its capacity. This solution was chosen because the extension of the road infrastructure would be quite demanding in terms of securing the available space and high investment costs.

Based on the presented data, a synthesis of partial evaluations of alternative solutions was realized. Its result is presented in Figure 12.

my decision

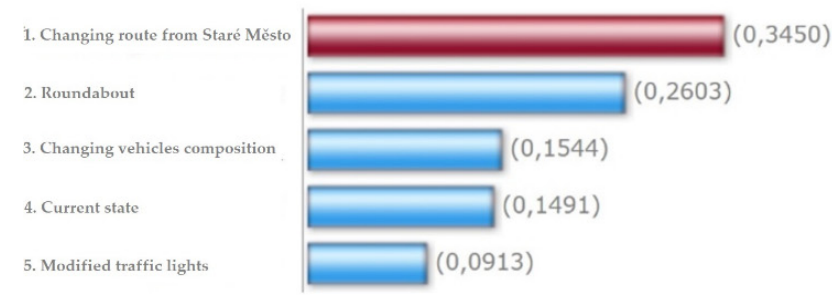

Alternatives rankings with structure

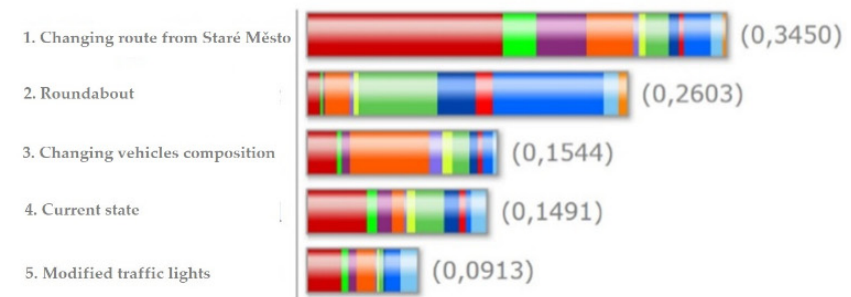

Figure 12. The result of alternatives compared with the help of the AHP method. 


\section{Conclusions}

The sustainability of transport in urban agglomerations is currently a key challenge to which constant attention is paid in the field of logistics. Approaches based on the use of computer simulation are widely used in the solution of partial needs related to transport sustainability.

Computer simulation presents a highly useful tool to resolve transport issues and should be applied as much as possible. Experts in transport and infrastructure should consider simulation models as invaluable working tools.

However, computer simulation is not a universal solution that can automatically solve all transport sustainability issues. Computer simulation in the field of transport is often used in the form of a support tool for obtaining broad-spectrum information, whose level of detail can be specified according to the requirements.

The ability of experts to effectively use and work with simulation models, their modification with the view to efficiently resolving transport issues should be a steady trend in the area of transport. In particular, microscopic simulation models, which may be applied to a large scale of transport problems and issues, should be employed at the outset.

In using computer simulation as a tool for obtaining a set of information covering different variants of the solutions to traffic problems, it is necessary to realize a final decision and select a suitable variant of the solutions. In these cases, multi-criteria decision-making appears to be an effective application, in which it is suitable to use the AHP method. The combination of computer simulation and multi-criteria decision-making is an effective analytical tool for solving traffic tasks related to the field of transport suitability.

This paper verifies, based on a practical example of a real traffic problem, possible solutions to the traffic problem using microscopic computer simulation and the AHP method. The investigated transport problem is associated with a change in the organization of the traffic hub and the selection of a suitable final variant.

The traffic hub was simulated using the PTV Vissim program, which is based on a multipurpose microscopic simulation of road traffic. After entering the required data (i.e., the number of vehicles, the traffic flow distribution, the permitted speed, and the light signalization interval) into the program, the output data were recorded. The applied results included information about the passing time of the vehicles, the length of the congestion, and the average delay of the vehicles at the intersection per simulated hour. Four simulation experiments were performed using the basic model, and the results obtained from these experiments were compared using multi-criteria decision-making via the AHP method.

The first experiment was oriented to changing the composition of the vehicles, thus excluding trucks from the intersection. The conditions of traffic were not improved significantly; rather, the conditions worsened.

Experiment no. 2 was focused on a change in traffic management in the direction from Staré Město, i.e., the vehicles were not allowed to turn from this direction toward the commercial zone. Comparing the results with the original situation, the traffic-carrying capacity improved by almost 1000 vehicles. The transit time was also more efficient and the length of the line of vehicles in the direction from Staré Město shortened.

Another experiment was focused on the application of a roundabout equipped with two traffic lanes. Passage of the vehicles through this intersection significantly worsened. The only positive result was the shortening of the line of vehicles in the direction from the commerce-industrial zone by $72 \%$.

The last experiment consisted of a change in the traffic light signalization. Signals were added for the turn options and the length of the green light was adjusted. The result of this last experiment was that more vehicles passed through the traffic hub. The passage of vehicles and the length of the column of cars changed slightly.

The evaluation of the experiments was based on a comparison of the length of congestion. The AHP method was used. Twelve criteria were used in multi-criteria decisionmaking, which was used to compare individual variants based on the results of simulation experiments and to select the optimal solution. 
According to the performed experiments, it is evident that the best solution for improvement of the traffic situation for the given traffic hub was derived from the experiment with the change in traffic management in the direction from Staré Město.

The presented procedure is a productive and reliable methodology that can be applied to solve a wide range of traffic problems. This enables us to make decisions, perform different types of analyses, and investigate the functioning of different types of transport processes.

The application of the model makes it possible to create guidelines for the priority measures in the field of public investment in urban infrastructure. The appropriateness of AHP in the field of transport is also presented by the research study [46], in which AHP is used for evaluation of the public passenger transport quality. In conclusion, it can be stated that the main novelty of the current paper is the combination of the simulation approach and the AHP model to select a suitable transport alternative. This is a solution that, according to the available information, has not yet been applied in this way to the area of urban transport. The paper was written to show a practical example of how it is possible to use a combination of discrete simulation and multi-criteria decision-making for the selection of solutions for the needs of transport sustainability. In terms of the combination of both methods for the field of transport sustainability, such a solution has not been obtained. The results presented follow several studies that have already been published. Creation of the discrete simulation model applied knowledge about the calibration and validation of the microscopic simulation model in the program PTV Vissim [47]. Application of the set of the optimal solution by the AHP method is related to the study focused on the creation of a traffic model of an intersection [48]. The paper also points out that multi-criteria decision-making can be also used for modeling a mixed traffic flow that passes a traffic junction and causes traffic congestions. New knowledge about this research problem is presented in [49]. The paper further indicates which data need to be focused on if there are several possible solutions in terms of transport sustainability within urban agglomerations. The paper thus extends the results that [50] presents marginally. The results presented extend the knowledge base presented in [51]. In contrast to the use of the AHP method for the process of transport organization in road tunnels, the present paper extends this issue to the area of intersections in built-up areas.

Author Contributions: Conceptualization, G.F. and V.M.; methodology, M.H. and N.M.; validation, G.F. and V.M.; formal analysis, N.M.; resources, R.K.; data curation, M.H.; writing-original draft preparation, G.F.; writing — review and editing, V.M. and V.S.; visualization, N.M. and V.S.; supervision, V.M.; project administration, R.K.; funding acquisition, G.F. All authors have read and agreed to the published version of the manuscript.

Funding: This work was supported by the projects of the Scientific Grant Agency of the Ministry of Education, Science, Research and Sport of the Slovak Republic and the Slovak Academy of Sciences (project No. VEGA 1/0403/18, VEGA 1/0638/19, and VEGA 1/0600/20) and by the projects of the Cultural and Educational Grant Agency of the Ministry of Education, Science, Research and Sport of the Slovak Republic and the Slovak Academy of Sciences (project No. KEGA 012TUKE-4/2019, KEGA 013TUKE-4/2019, KEGA 049TUKE-4/2020, and APVV SK-SRB-18-0053).

Institutional Review Board Statement: Not applicable.

Informed Consent Statement: Not applicable.

Data Availability Statement: The presented data can be obtained by email from corresponding author.

Conflicts of Interest: The authors declare no conflict of interest. 


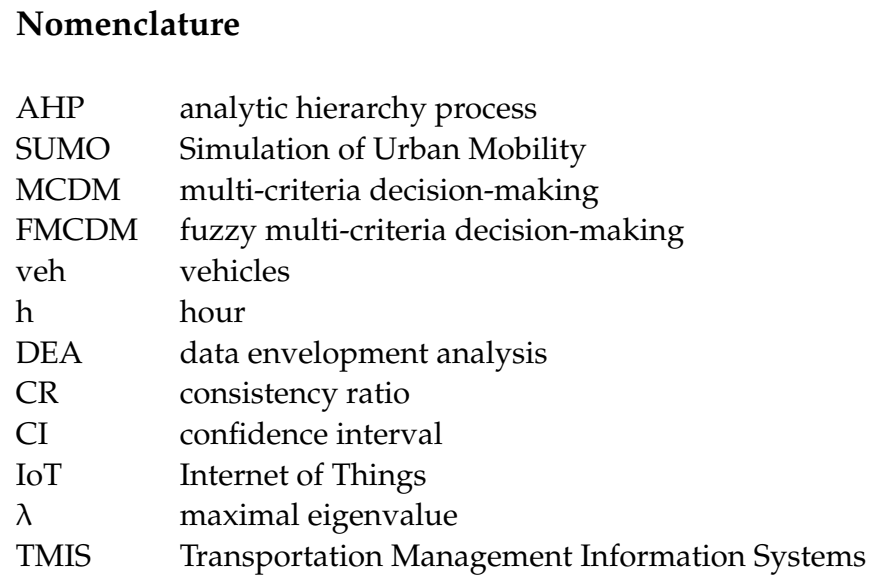

\section{References}

1. Balasubramaniam, A.; Paul, A.; Hong, W.H.; Seo, H.C.; Kim, J.H. Comparative analysis of intelligent transportation systems for sustainable environment in Smart Cities. Sustainability 2017, 9, 1120. [CrossRef]

2. Vujadinović, R.; Jovanović, J.Š.; Plevnik, A.; Mladenovič, L.; Rye, T. Key challenges in the status analysis for the sustainable urban mobility plan in podgorica, montenegro. Sustainability 2021, 13, 1037. [CrossRef]

3. Barkenbus, J.N. Eco-driving: An overlooked climate change initiative. Energy Policy 2010, 38, 762-769. [CrossRef]

4. Zhao, L.; Jia, Y. Intelligent transportation system for sustainable environment in smart cities. Int. J. Electr. Eng. Educ. 2021. [CrossRef]

5. Hu, J.; Zhang, Z.; Xiong, L.; Wang, H.; Wu, G. Cut through traffic to catch green light: Eco approach with overtaking capability. Transp. Res. Part C Emerg. Technol. 2021, 123, 102927. [CrossRef]

6. Hamurcu, M.; Eren, T. Electric bus selection with multicriteria decision analysis for green transportation. Sustainability 2020, 12, 2777. [CrossRef]

7. Yan, B. Improvement of the economic management system based on the publicity of railway transportation products. Intell. Autom. Soft Comput. 2020, 26, 539-547. [CrossRef]

8. Liu, J.; Kang, X.; Dong, C.; Zhang, F. Simulation of real-time path planning for large-scale transportation network using parallel computation. Intell. Autom. Soft Comput. 2019, 25, 65-77. [CrossRef]

9. Deng, D.; Shahabi, C.; Demiryurek, U.; Zhu, L.; Yu, R.; Liu, Y. Latent space model for road networks to predict time-varying traffic. In Proceedings of the 22nd ACM SIGKDD International Conference on Knowledge Discovery and Data Mining, San Francisco, CA, USA, 13-17 August 2016; pp. 1525-1534.

10. Gao, H.; Huang, W.; Yang, X. Applying probabilistic model checking to path planning in an intelligent transportation system using mobility trajectories and their statistical data. Intell. Autom. Soft Comput. 2019, 25, 547-559. [CrossRef]

11. Codeca, L.; Frank, R.; Faye, S.; Engel, T. Luxembourg SUMO Traffic (LuST) Scenario: Traffic Demand Evaluation. IEEE Intell. Transp. Syst. Mag. 2017, 9, 52-63. [CrossRef]

12. Lèbre, M.A.; Le Mouël, F.; Ménard, E. On the importance of real data for microscopic urban vehicular mobility trace. In Proceedings of the 2015 14th International Conference on ITS Telecommunications (ITST 2015), Copenhagen, Denmark, 2-4 December 2016; pp. 22-26.

13. Liu, W.; Tang, Y.; Yang, F.; Zhang, C.; Cao, D. Internet of things based solutions for transport network vulnerability assessment in intelligent transportation systems. Comput. Mater. Contin. 2020, 65, 2511-2527. [CrossRef]

14. Wang, J.; Yang, Y.; Wang, T.; Sherratt, R.; Zhang, J. Big Data Service Architecture: A Survey. J. Internet Technol. 2020, $21,393-405$. [CrossRef]

15. Zhang, J.; Zhong, S.; Wang, T.; Chao, H.-C.; Wang, J. Blockchain-Based Systems and Applications: A Survey. J. Internet Technol. 2020, 21, 1-14. [CrossRef]

16. PTV Group. Available online: https://www.ptvgroup.com/en/solutions/products/ptv-vissim (accessed on 1 April 2021).

17. Shams, A.; Zlatkovic, M. Effects of capacity and transit improvements on traffic and transit operations. Transp. Plan. Technol. 2020, 43, 602-619. [CrossRef]

18. Jehad, A.E.; Ismail, A.; Borhan, M.N.; Ishak, S.Z. Modelling and optimizing of electronic toll collection (ETC) at Malaysian toll plazas using microsimulation models. Int. J. Eng. Technol. 2018, 7, 2304-2308. [CrossRef]

19. Yulianto, B. Traffic Management and Engineering Analysis of the Manahan Flyover Area by using Traffic Micro-Simulation VISSIM. IOP Conf. Ser. Mater. Sci. Eng. 2020, 852, 012005. [CrossRef]

20. Jeihani, M.; James, P.; Saka, A.A.; Ardeshiri, A. Traffic recovery time estimation under different flow regimes in traffic simulation. J. Traffic Transp. Eng. 2015, 2, 291-300. [CrossRef]

21. Golshan Khavas, R.; Hellinga, B.; Zarinbal Masouleh, A. Identifying parameters for microsimulation modeling of traffic in inclement weather. Transp. Res. Rec. 2017, 2613, 52-60. [CrossRef]

22. Li, Z.; Chitturi, M.; Zheng, D.; Bill, A.; Noyce, D. Modeling reservation-based autonomous intersection control in VISSIM. Transp. Res. Rec. 2013, 2381, 81-90. [CrossRef] 
23. Camargo Pérez, J.; Carrillo, M.H.; Montoya-Torres, J.R. Multi-criteria approaches for urban passenger transport systems: A literature review. Ann. Oper. Res. 2015, 226, 69-87. [CrossRef]

24. Patil, A.; Herder, P.; Brown, K. Investment Decision Making for Alternative Fuel Public Transport Buses: The Case of Brisbane Transport. J. Public Transp. 2010, 13, 115-133. [CrossRef]

25. Mukherjee, S. Selection of Alternative Fuels for Sustainable Urban Transportation under Multi-criteria Intuitionistic Fuzzy Environment. Fuzzy Inf. Eng. 2017, 9, 117-135. [CrossRef]

26. Yedla, S.; Shrestha, R.M. Multi-criteria approach for the selection of alternative options for environmentally sustainable transport system in Delhi. Transp. Res. Part A Policy Pract. 2003, 37, 717-729. [CrossRef]

27. Pogarčić, I.; Frančić, M.; Davidović, V. Application of ahp method in traffic planning. In 16th International Symposium on Electronics in Traffic; Meše, P., Hernavs, B., Eds.; Electrotechnical Association of Slovenia: Ljubljana, Slovenia, 2008; pp. 1-8.

28. Effat, H.A.; Hassan, O.A. Designing and evaluation of three alternatives highway routes using the Analytical Hierarchy Process and the least-cost path analysis, application in Sinai Peninsula, Egypt. Egypt. J. Remote Sens. Space Sci. 2013, 16, 141-151. [CrossRef]

29. Karunanayake, K.T.S.; Weerakoon, W.M.N.R.; Wickramasinghe, V. Use of analytic hierarchy process (AHP) for solving traffic issues due to ad-hoc urban planning. In International Conference on Sustainable Built Environment; Iniversity of Moratuwa, Sri Lanka: Kandy, Sri Lanka, 2012; pp. 1-13.

30. Kutlu Gündoğdu, F.; Duleba, S.; Moslem, S.; Aydın, S. Evaluating public transport service quality using picture fuzzy analytic hierarchy process and linear assignment model. Appl. Soft Comput. 2021, 100, 106920. [CrossRef]

31. Villegas Flores, N.; Cruz Salvador, L.C.; Parapinski dos Santos, A.C.; Madero, Y.S. A proposal to compare urban infrastructure using multi-criteria analysis. Land Use Policy 2021, 101, 105173. [CrossRef]

32. Shekhovtsov, A.; Kozlov, V.; Nosov, V.; Sałabun, W. Efficiency of methods for determining the relevance of criteria in sustainable transport problems: A comparative case study. Sustainability 2020, 12, 7915. [CrossRef]

33. Awasthi, A.; Chauhan, S.S. Using AHP and Dempster-Shafer theory for evaluating sustainable transport solutions. Environ. Model. Softw. 2011, 26, 787-796. [CrossRef]

34. PTV Group AG. Vissim 7 User Manual. Available online: https://www.scribd.com/document/287732324/Vissim-7-Manualtransfer-ro-25nov-ccb8e5-pdf (accessed on 15 March 2018).

35. Saaty, T.L.; Joyce, A.M. Thinking with Models, 1st ed.; Pergamon Press: Oxford, UK, 1981; ISBN 0-08-026475-1.

36. Saaty, T.L. A scaling method for priorities in hierarchical structures. J. Math. Psychol. 1977, 15, 234-281. [CrossRef]

37. Bartošíková, R.; Bilíková, J.; Strohmandl, J.; Šef̌ćik, V.; Taraba, P. Modelling of decision-making in crisis management. In Proceedings of the 24th International Business Information Management Association Conference-Crafting Global Competitive Economies: 2020 Vision Strategic Planning and Smart Implementation, Milan, Italy, 6-7 November 2014; International Business Information Management Association, IBIMA: Norristown, PA, USA, 2014; pp. 1479-1483.

38. Kengpol, A.; Tuammee, S. The development of a decision support framework for a quantitative risk assessment in multimodal green logistics: An empirical study. Int. J. Prod. Res. 2016, 54, 1020-1038. [CrossRef]

39. Koohathongsumrit, N.; Meethom, W. Route selection in multimodal transportation networks: A hybrid multiple criteria decision-making approach. J. Ind. Prod. Eng. 2021, 38, 171-185. [CrossRef]

40. De Felice, F.; Petrillo, A. A new multicriteria methodology based on Analytic Hierarchy Process: The "Expert" AHP. Int. J. Manag. Sci. Eng. Manag. 2010, 5, 439-445. [CrossRef]

41. Russo, R.D.F.S.M.; Camanho, R. Criteria in AHP: A systematic review of literature. Procedia Comput. Sci. 2015, 55, 1123-1132. [CrossRef]

42. Roháčová, I.; Marková, Z. Analýza metódy AHP a jej potenciálne využitie v logistike. Acta Montan. Slovaca 2009, 14, 103-112.

43. Mikušová, M.; Čopíková, A. Using the method of multi-criteria decision making to determine the competency model of crisis manager. In DIEM-Dubrovnik International Economic Meeting; University of Dubrovnik: Dubrovnik, Croatia, 2015 ; pp. 470-486.

44. Rohrbach, B. Kreativ nach Regeln-Methode 635, eine neue Technik zum Lösen von Problemen. Absatzwirtschaft 1969, 12, 73-76.

45. Wilson, C. Using Brainwriting For Rapid Idea Generation. Available online: https://www.smashingmagazine.com/2013/12/ using-brainwriting-for-rapid-idea-generation/ (accessed on 13 December 2013).

46. Moslem, S.; Çelikbilek, Y. An integrated grey AHP-MOORA model for ameliorating public transport service quality. Eur. Transp. Res. Rev. 2020, 12, 68. [CrossRef]

47. Jayasooriya, N.; Bandara, S. Calibrating and Validating VISSIM Microscopic Simulation Software for the Context of Sri Lanka. In Proceedings of the 2018 Moratuwa Engineering Research Conference (MERCon), Moratuwa, Sri Lanka, 30 May-1 June 2018.

48. Fabianova, J.; Michalik, P.; Janekova, J.; Fabian, M. Design and evaluation of a new intersection model to minimize congestions using VISSIM software. Open Eng. 2020, 10, 48-56. [CrossRef]

49. Bede, Z.; Nemeth, B.; Gaspar, P. Simulation-based analysis of mixed traffic flow using VISSIM environment. In Proceedings of the 2017 IEEE 15th International Symposium on Applied Machine Intelligence and Informatics (SAMI), Herl'any, Slovakia, 26-28 January 2017.

50. Huang, F.; Liu, P.; Yu, H.; Wang, W. Identifying if VISSIM simulation model and SSAM provide reasonable estimates for field measured traffic conflicts at signalized intersections. Accid. Anal. Prev. 2013, 50, 1014-1024. [CrossRef]

51. Wang, P.Q.; Lu, Z.G.; Zhang, H.Q.; Wang, F.J. Using Analytic Hierarchy Process to evaluate the improvement schemes of the Maoliling Tunnel based on the VISSIM simulation. In Proceedings of the 4th International Conference on Civil Engineering and Urban Planning (CEUP), Beijing, China, 25-27 July 2015. 